\title{
Current Status and Future Perspectives of Supports and Protocols for Enzyme Immobilization
}

\author{
Francisco T. T. Cavalcante ${ }^{1}\left(\mathbb{D}\right.$, Antônio L. G. Cavalcante ${ }^{2} \mathbb{D}$, Isamayra G. de Sousa ${ }^{3}$, Francisco S. Neto ${ }^{3} \mathbb{D}$ \\ and José C. S. dos Santos ${ }^{3, *}$ \\ 1 Departamento de Engenharia Química, Campus do Pici, Universidade Federal do Ceará, Bloco 709, \\ Fortaleza CEP 60455760, CE, Brazil; thalysson.cavalcante13@gmail.com \\ 2 Departamento de Química Analítica e Físico-Química, Campus do Pici, Universidade Federal do Ceará, \\ Bloco 940, Fortaleza CEP 60455760, CE, Brazil; luthi2011@gmail.com \\ 3 Instituto de Engenharias e Desenvolvimento Sustentável, Campus das Auroras, Universidade da Integração \\ Internacional da Lusofonia Afro-Brasileira, Redenção CEP 62790970, CE, Brazil; \\ isamaayra@gmail.com (I.G.d.S.); fcosimao@aluno.unilab.edu.br (F.S.N.) \\ * Correspondence: jcs@unilab.edu.br
}

Citation: Cavalcante, F.T.T.;

Cavalcante, A.L.G.; de Sousa, I.G.; Neto, F.S.; dos Santos, J.C.S. Current Status and Future Perspectives of Supports and Protocols for Enzyme Immobilization. Catalysts 2021, 11, 1222. https://doi.org/10.3390/ catal11101222

Academic Editor: David D. Boehr

Received: 17 September 2021

Accepted: 8 October 2021

Published: 11 October 2021

Publisher's Note: MDPI stays neutral with regard to jurisdictional claims in published maps and institutional affiliations.

Copyright: (c) 2021 by the authors. Licensee MDPI, Basel, Switzerland. This article is an open access article distributed under the terms and conditions of the Creative Commons Attribution (CC BY) license (https:// creativecommons.org/licenses/by/ $4.0 /)$.

\begin{abstract}
The market for industrial enzymes has witnessed constant growth, which is currently around $7 \%$ a year, projected to reach $\$ 10.5$ billion in 2024. Lipases are hydrolase enzymes naturally responsible for triglyceride hydrolysis. They are the most expansively used industrial biocatalysts, with wide application in a broad range of industries. However, these biocatalytic processes are usually limited by the low stability of the enzyme, the half-life time, and the processes required to solve these problems are complex and lack application feasibility at the industrial scale. Emerging technologies create new materials for enzyme carriers and sophisticate the well-known immobilization principles to produce more robust, eco-friendlier, and cheaper biocatalysts. Therefore, this review discusses the trending studies and industrial applications of the materials and protocols for lipase immobilization, analyzing their advantages and disadvantages. Finally, it summarizes the current challenges and potential alternatives for lipases at the industrial level.
\end{abstract}

Keywords: lipase; immobilization; support; protocol; biocatalysis; co-immobilization; biocatalyst; enzyme; novel techniques

\section{Introduction}

The continuous interest of the market and the academy in biotechnological alternatives to the waste of byproducts and power attached to conventional industrial processes are opening and exploring new study fields in biocatalysis. However, there are still many potentials to be exploited in this subject [1-4]. The enzyme market is growing by around $7 \%$ a year, relying on new ways of cheapening their use and the well-known advantages of mild reaction conditions, specificity, reduced byproduct formation, product separation, biodegradability, and high efficiency [5-8].

Lipases are triacylglycerol ester hydrolases (EC 3.1.1.3) that act on a wide variety of substrates such as triacylglycerides, esters of fatty acids, and lipids from synthetic or natural oils [9-19]. Their natural action involves the hydrolysis of triglycerides to free fatty acids and glycerol. However, acyl transfer reaction on the hydrolysis of ester bonds can also create $\mathrm{C}-\mathrm{C}$ bonds, acting in a wide range of solvents, making them one of the most widely used enzymes in industrial processes [6,20]. Their main biotechnological applications are in the biotransformation of oils and fats in food, pharmaceutical, cosmetic, and power production industries [21-34]

Lipases can be from animal, microbial, and plant sources, with varying properties $[12,21,35]$. However, almost $50 \%$ of the commercial volume of lipases is produced only from yeasts and filamentous fungi [36,37]. Lipase structure is built on the $\alpha / \beta$ 
hydrolase fold composed of a core of eight predominant parallel $\beta$ filaments, forming a twisted central $\beta$ sheet, surrounded by a variable number of $\alpha$ helices $[38,39]$. Their catalytic triad is composed of nucleophilic serine, histidine, and glutamate or aspartate $[38,39]$. They also have an oxyanion orifice responsible for stabilizing the oxygen ion formed as an intermediate reaction during catalysis [35,40]. Lipases usually have a chain of hydrophobic amino acids that covers the active site called the lid, which acts to control the access of the substrate to the active site of the lipase, giving it an open-closed shape, which can be conformationally changed by the presence of a polar-nonpolar interface [38,41].

Despite the presented advantages, lipase production suffers from non reproducibility and low yields in their cultivation stage [42,43]. Furthermore, regarding their application, free-state lipases (or free enzymes in general) have limitations such as sensitivity to the reaction medium and low operational stability, making their industrial use practical only by their immobilization [44-46]. Immobilization methods are good alternatives that can favor enzyme activity, facilitate biocatalyst recovery, modulate its selectivity and specificity, and improve resistance to inhibitors [44-59].

Meeting with the current public policies for green and sustainable development, the interest in using immobilized lipases in industrial processes results in increased funding for the studies thereof, causing new support materials and immobilization processes to be discovered and improved [60-68]. In this sense, this study presents the latest research trends in the production of lipase biocatalysts and their optimized industrial applications.

\section{Novel Techniques for Lipase Immobilization}

Physical and chemical interactions between supports and enzymes define the linkage of the immobilized biocatalyst [69-73]. The developed technologies and methods for this procedure still use one or more basic strategies: adsorption, encapsulation, covalent bonding, entrapment, and crosslinking. Thus, they may retain their base method's good and bad qualities $[6,69,74-76]$.

Adsorption is the simplest method, which requires the use of reactants [77]. The physical and chemical groups of the matrix interact with the enzyme and retain it [78]. In this way, this method is more susceptible to enzyme leakage [77,78]. Encapsulation is a method that maintains the enzyme in its original conformation and brings excellent mechanical and storage stability [79]. On the other hand, the substrate may have difficulty accessing the enzyme's active site, leading to mass transfer limitations and reduced yields of reactions $[79,80]$. Entrapment is a similar technique, but it uses a different matrix type, is more accessible, cheaper, and allows for a better substrate diffusion [78]. However, it generally has low operational stability and higher enzyme leakage $[78,81,82]$. Covalent bonding is the most used method, which requires chemical reactants to create functional groups that will bond with the enzyme $[6,69,83-87]$. This strategy can offer significant operational stability and reusability to the biocatalyst, but it may cause conformational changes in the enzymes during the immobilization procedure, reducing or even extinguishing enzyme activity $[6,74,88]$. Using the principles briefly presented in this paragraph, the following subsections present the trending protocols for lipase immobilization.

\subsection{Crosslinked Enzyme Aggregates (CLEAs)}

The technique of immobilization by enzymatic aggregates (CLEAs) is characterized as a helpful and straightforward technique, having such advantages as permanent insolubility and excellent thermal stability $[89,90]$. Using this method, the structure of the enzyme is conserved, retaining the activity of its catalyst. Furthermore, it allows two or more enzymes to co-immobilize more quickly than other immobilization protocols [91,92]. Crosslinked enzymatic aggregates are among the recent immobilization methods that do not use solid supports and have been requested over the past few years for their ease and robustness, in addition to promoting high specific activity and not requiring highly purified enzymes $[93,94]$. It is a protocol that combines different preparation steps, such as purification, precipitation, and immobilization, in one, making the process simpler and 
faster $[95,96]$. Thus, they are prepared by enzymatic precipitation to form aggregates, produced by mixing the protein with precipitating agents (e.g., ammonium sulfate, organic solvents, or polymers) in aqueous solutions, as shown in Figure $1[97,98]$.

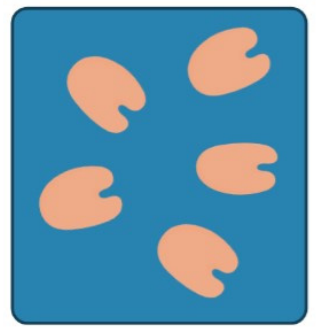

Free enzyme

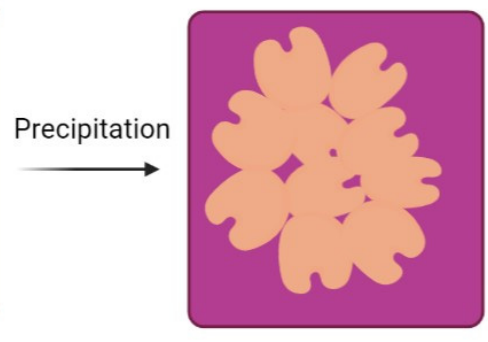

Aggregated enzyme

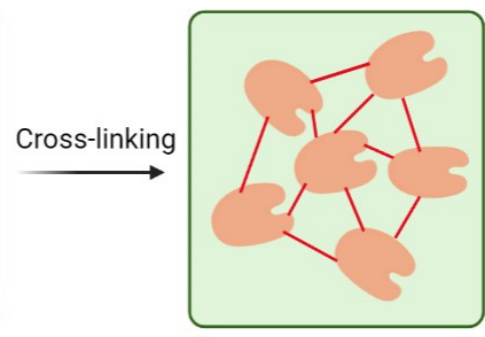

Cross-linked enzyme aggregated

Figure 1. Representation of precipitation and crosslinking steps for the formation of crosslinked enzymatic aggregates.

Thus, these enzyme aggregates are crosslinked with a crosslinking agent, usually glutaraldehyde [99-102]. The crosslinking step generates the covalent bonds between the amino acids (specific lysines) of the protein molecules, producing an insoluble biocatalyst with high stability and activity [103]. Different concentrations of glutaraldehyde can influence the leaching process of the immobilized enzyme. Low concentrations of glutaraldehyde make the enzyme fixation process easier [104-106]. In contrast, a higher glutaraldehyde concentration enables many aldehyde groups that interact with the enzyme, making the enzyme immobilization process more efficient and preventing leaching [107-109]. The presence of glutaraldehyde as a functional binding agent contributes to high stability in immobilized enzymes. Covalent bonds formed by enzyme amino groups and aldehyde groups decrease molecular flexibility. This fact suggests positively the increased conformational stability of proteins and, consequently, excellent thermal stability [90,110-112].

The manufacturing process of CLEAs is cost-effective as it does not require the use of preexisting expensive carriers and generally affects heterogeneous biocatalysts with high volumetric activities $[113,114]$. Furthermore, coaggregation agents (co-feeders) such as polymers or proteins are suggested to enhance inter-enzyme crosslinking [115]. It has been successfully applied in the immobilization of several different types of enzymes such as hydrolases [90], oxidoreductases [116], lyases [117], transferases [118], and isomerases [119] used in the manufacturing of chemical products, being subject to an increasing number of analyses $[120,121]$.

In the study by Rehman et al. (2016) [90], a lipase from Penicillium notatum (PNL) was immobilized through crosslinked enzyme aggregates using glutaraldehyde (GLA) and ethylene glycol-bis (succinic acid $N$-hydroxysuccinimide) (EG-NHS) as crosslinking agents. EG-NHS aggregates showed higher hydrolytic activities and esterification compared to GLA aggregates. The highest enzyme activity of CLEAs was reached at $\mathrm{pH} 9.0$ and a temperature of $42{ }^{\circ} \mathrm{C}$. Furthermore, there was a significant improvement in thermal resistance after immobilization. Finally, after ten reuse cycles in aqueous media, GLA and EG-NHS crosslinked lipase CLEAs preserved $63.62 \%$ and $70.9 \%$ of their original activities, respectively, suggesting that this new CLEA lipase demonstrates potential in many industrial applications [90].

In another study by Jin et al. (2019) [92], the lipase r27RCL from Rhizopus chinensis was immobilized in octyl-modified microcellular foams (MCFs-C8) using the crosslinking method. As a result, the crosslinked enzymatic lipase aggregates (CLEAs) exhibited better esterification activity than their adsorbed form. Furthermore, the biocatalyst exhibited excellent thermal and mechanical stability and could maintain $69 \%$ of the initial activity after five reaction cycles [92]. More recent work by Muley et al. in 2021 [122] was based on the preparation of crosslinked enzymatic aggregates (CLEAs) of lipase from Aspergillus 
niger using fractional precipitation with ammonium sulfate and crosslinking with glutaraldehyde. In the end, lipase CLEAs showed better thermostability than its free form, in addition to retaining more than $65 \%$ of its activity for up to four cycles, exhibiting good storage stability for 12 days when stored at $4 \pm 2{ }^{\circ} \mathrm{C}$. Furthermore, they were successful in the application for epoxidation of lemongrass oil [122].

\subsection{Covalent Organic Frameworks (COFs)}

$\mathrm{COFs}$ are characterized as porous organic polymeric materials, generally crystalline, obtained through polymerizing building blocks of organic binders [123-126]. They have atomically precise porous structures and can have excellent chemical stability in organic solvents, resisting adverse conditions such as acidic and basic conditions to maintain orderly structures and crystallinity $[127,128]$. In addition, their high stability results from the purely covalent bond and metal-free structures $[127,129]$. Due to their excellent properties, such as high thermal and chemical stability, large surface area, excellent pore properties, traceable physical and chemical properties, and ease of operation, COFs exhibit excellent performance in the areas of gas storage and separation, analytical chemistry, catalysis, electrical and storage devices, optoelectronics and drug detection [130-133]. Sustainability is one of their most important properties, distinguishing them from other adsorbents; very stable at $250{ }^{\circ} \mathrm{C}$ and $450{ }^{\circ} \mathrm{C}$ in an inert atmosphere [134].

Generally, these COFs are synthesized through a solvothermal method under adverse conditions, such as high temperature, ranging between $80^{\circ} \mathrm{C}$ and $120^{\circ} \mathrm{C}$, high pressure, where the reaction is carried out in a Teflon-lined stainless steel autoclave or a sealed Pyrex tube, and strict deoxidation, where oxygen is removed by freeze-thaw cycling [135-137]. Due to intermolecular interactions, when monomer molecules contain more groups, material synthesis can be affected, making it challenging to form regular crystalline materials this way [138]. Thus, another advantage of COFs is that their organic structure can be modified to adjust their properties, favoring synthesis [139,140].

In recent years, the application of COFs as supports for enzyme immobilization has opened new horizons for researchers due to their excellent and unique properties, such as marked stability, porous and crystalline structure, in addition to a large accessible surface area [141,142]. The integration of enzymes and COFs can occur through different possibilities, including physical adsorption and covalent bonding directly between them or through a binding molecule [143]. Figure 2 shows how this process takes place.

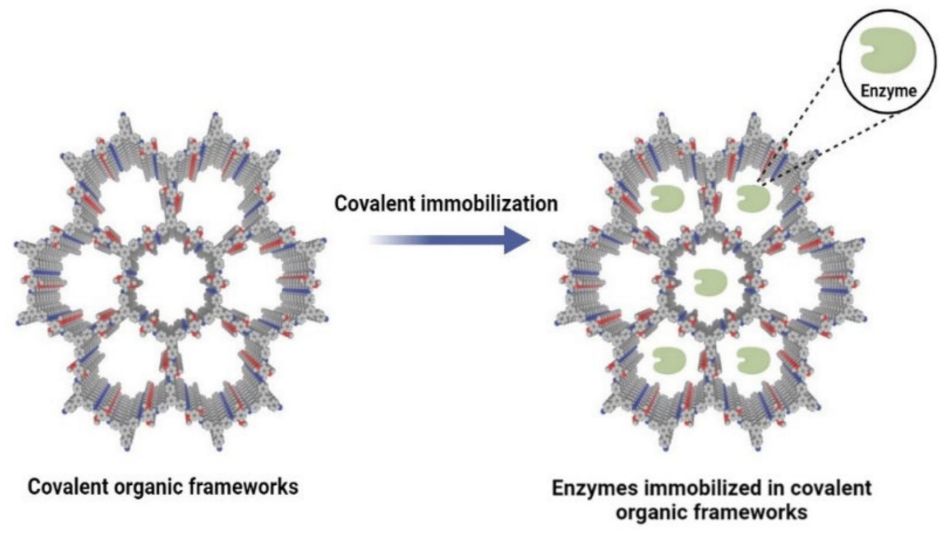

Figure 2. Covalent immobilization of enzymes in COFs.

Catalysts based on COFs have particular advantages over traditional catalysts. Their structures and compositions projectable by chemical crosslinking provide a better understanding regarding the activity and investigation of the catalytic mechanism. In contrast, the highly uniform and adjustable pore structures and sizes facilitate the mass transfer, screening, confinement, and access to catalytic sites $[144,145]$. The high thermal and chemi- 
cal stabilities of COFs ensure that they continue catalytic reaction in various media, which is problematic for some MOFs and inorganic zeolites [144,146].

Currently, there is still little research related to the immobilization of enzymes in COFs. However, studies have been carried out with promising results. According to Zhou et al. (2021) [147], accessible synthesis of a core-shell magnetic COF composite $\left(\mathrm{Fe}_{3} \mathrm{O}_{4} @\right.$ @ COFOMe) immobilizing Rhizomucor miehei lipase (RML) to allow for its application in biodiesel production was reported. As a result, the magnetic structure of COF-OMe achieves highly efficient immobilization and recovery processes and maintains lipase activity to a large extent. The new biocatalyst performed well in practical applications, while the free lipase did not. Furthermore, it successfully produced biodiesel from Jatropha curcas oil with a yield of around $70 \%$ under optimized conditions [147].

Finally, the process of enzyme immobilization in COF materials is facilitated by their porous structure, high stability, ability to modulate, crystalline, flexible surface area, and the presence of different functional groups [148-152]. These functional groups enable different interactions via hydrogen bonding, hence their increased molecule adsorption capacity. In this context, the immobilization of enzymes in COFs via physical adsorption has an advantage over covalent immobilization. Printing COFs with immobilized enzyme molecules is possible for producing versatile and selective materials [145,153-157] in addition to the possibility of multi-enzyme and porous systems for industrial application.

\subsection{Metal-Organic Frameworks (MOFs)}

Metal-organic frameworks (MOFs), also known as porous coordination polymers (PCPs), are built with inorganic nodes and possibly metal ions or clusters with organic ligands [158-160]. This category of materials appears as a promising class with several unique properties such as high porosity, diverse composition, adjustable pore structure, and versatile functionality, bringing merit to different applications ranging from catalysis to storage, separation, purification, and water remediation [161-169].

Opposing traditional inorganic materials, MOFs allow controlling their composition, morphology, pore properties, and function through the careful selection of construction units in addition to the incorporation of intelligent functionalities, expanding and improving their efficiency in specific applications [170-172]. The catalytic activity of MOFs comes from uncoordinated metal centers or functional groups attached to the structure's ligands [173]. In addition, catalysts such as nanoparticles, metal complexes, or biomolecules can be added inside the MOF cage or anchored to its surface as it offers stability to active catalysts and can act as size-selective catalyst support [174-177].

MOFs with the largest surface area and adjustable porosity properties provide the loading of more enzymes than conventional carrier materials. In addition, the shielding effect of their structure allows for stabilization of the enzyme's conformational structure, improving its stability $[178,179]$. Generally, the preparation of enzymes immobilized in MOFs is based on three strategies: encapsulation, surface immobilization, and pore trapping with presynthesized MOFs [180]. Enzymes encapsulated in porous materials such as porous nanoparticles or reversible micelles have better stability under adverse conditions such as high temperature, organic solvents, or extreme $\mathrm{pH}$ [181-183]. Figure 3 presents enzyme encapsulation in MOFs.

In work carried out by Cui et al. (2018) [184], a new MOF-enzyme compound was produced with high stability and easily reusable features through the encapsulation of catalase and ZIF-8 nanocrystals in large layers of mesoporous silica. The obtained system exhibited high activity recovery reaching $81 \%$, and the silica provided a shield to protect the enzyme from biological and chemical degradation. It exhibited excellent stability against proteolytic agents and extreme conditions, such as low $\mathrm{pH}$, in addition to the remaining $50 \%$ of the original activity after ten cycles [184]. 


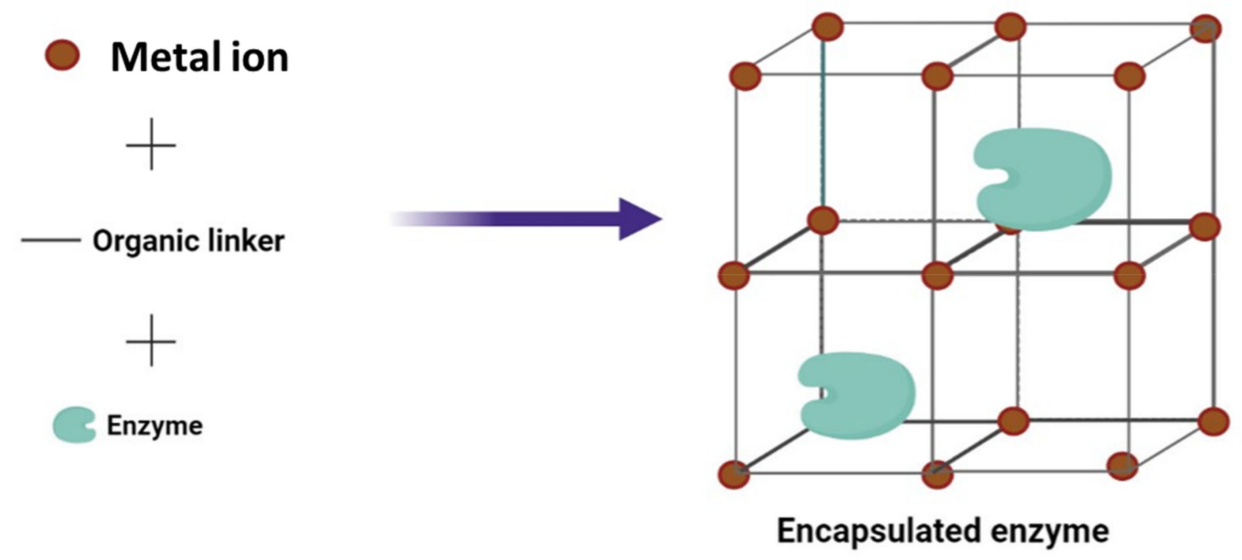

Figure 3. Enzyme encapsulation in metal-organic frameworks.

The work carried out by Li et al. in 2020 [185] was based on the immobilization of the thermophilic lipase QLM from Alcaligenes sp. in MOFs through biomimetic mineralization using zinc acetate and adenine as a metal ion and an organic binder, respectively. The immobilized enzyme was successful when applied in the preparation of biodiesel through the transesterification of sunflower oil with methanol, obtaining a conversion more significant than $60 \%$ at a high oil/methanol ratio of $8: 1$. It also showed excellent recyclability during biodiesel production, where no changes in morphology and crystal structure were observed after three cycles. The results proved that the lipase immobilized in bio-based MOFs provided an economical, environmentally friendly, and viable solution for biodiesel synthesis [185].

In the context of enzyme immobilization, MOFs stand out for their high specific surface area, pore-volume, adjustable porosity, high thermal and chemical stability, as well as adjustable mechanical stability [186-189]. MOFs modulate the properties of enzymes. That is, they enable different functionalization, sizes, morphology, and different electrostatic potentials [186-188]. These characteristics are essential to provide excellent stabilization and activity of enzymes at high temperatures, in the media with high acidity or high alkalinity, or in the presence of organic solvents $[190,191]$. The possibility of synergistic catalysis of MOFs and enzymes is very promising for industrial application [192].

\section{4. $3 D$ Printing}

In recent years, three-dimensional (3D) printing, also known as additive manufacturing, has emerged as a technology that uses computer-aided design (CAD) for layer-on-layer fabrication, having many advantages over traditional technologies [193-195]. Low cost and endless design possibilities have made this approach very interesting for prototyping in many fields, including process design, aerospace engineering, biomedicine, and catalysis $[196,197]$. In addition, complex structures with a resolution of up to $0.01 \mathrm{~mm}$ can be quickly produced with various materials ranging from polymers to metals [198].

In order to increase compatibility with biological materials, a variety of methods and materials for extrusion-based 3D bioprinting can generate custom hydrogel structures, as shown in Figure $4[199,200]$. These hydrogels can trap enzymes without specific adaptations, offering protection against organic solvents and modulating the reaction rate through mass transfer limitations since 3D-printed structures are relatively thick [201,202]. In addition, chemical modification of printed materials has attracted increasing attention, as by modifying printed carriers, enzymes can be immobilized on them [203].

Enzyme trapping is often applied together with 3D-printed support materials, and, in addition, trapping in this physical material allows the enzyme to be retained in the reactor and provides sufficient purification. The applicability of 3D-printed carriers has been investigated using different enzymes and under different conditions, indicating the universal performance of these materials and their processes $[8,204,205]$. Therefore, this 
new immobilization strategy offers an encouraging possibility to extend the useful life of enzymes [206].

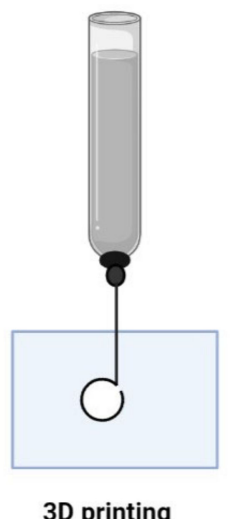

3D printing

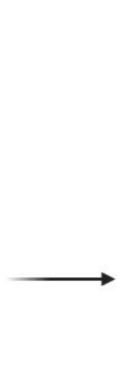$$
\text { Hy }
$$

Hydrog
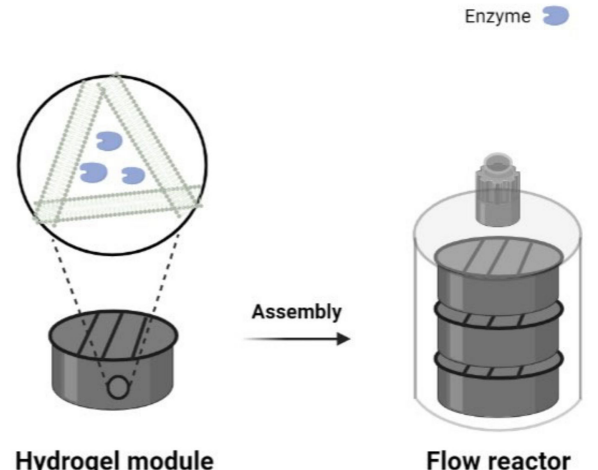

Figure 4. Diagram of the 3D printing process for enzyme immobilization.

The study by Santos et al. (2021) [207] produced network-shaped geopolymers successfully prepared by direct ink writing (an additive manufacturing process) to act as carriers for the immobilization of Candida rugosa lipase (CRL). The biocatalyst was evaluated in the hydrolysis of residual cooking oil (WCO), a preliminary step for producing biodiesel. The surface of the geopolymer was successfully modified to allow for the covalent bond immobilization process of the CRL. The hydrolytic activity reached $847.7 \pm 9.7 \mathrm{U} / \mathrm{g}$ and remained more significant than $91 \%$ after the first reuse. A free fatty acid content of $75 \%$ by weight was obtained from the hydrolysis of WCO, affirming the immobilization efficiency and the suitability of network-shaped geopolymers as support for biocatalysts [207].

In another study, Zhang et al. (2021) [206] built an eco-friendly 3D printing macroscaffold based on reinforced polylactic acid (PLA) and added phenyl groups with different bond lengths and anchoring two types of combined groups for bonding Burkholderia ambifaria lipase YCJ01. The results obtained improved the payload, increased the enzyme expression, ensured $137.3 \%$ activity recovery, and increased the specific activity. The biocatalyst was applied to the efficient resolution of racemic 1-indanol $(267 \mathrm{mM})$ using a binary solvent system with high stereoselectivity. In the end, it presented good operational stability with repetitive use for nine cycles, being beneficial to obtain a pure product with high enantiomeric value by viable separation without rigorous operation [206].

In this way, the immobilization of lipases and other enzymes with 3D structures opens up several possibilities. The possibility of pre-casting these structures with different pore sizes, such as microstructures and porous membranes, is a reality [208-210]. These structures with different groups, receptors, sensitivity to perform immobilization, and production and low-cost materials to achieve these goals make the material produced more competitive for industrial applications [211-215].

\subsection{Electrospinning}

Immobilization techniques have become a rational project subject due to the nature of enzymes and the functionality of immobilization [216-218]. The improvement and innovation in enzyme immobilization techniques made it possible to overcome some common limitations [216-220]. Electrospinning is a practical, simple, and highly efficient technological tool for synthesizing ultrafine fibers with diameters in the range of nanometers $[216,219,221,222]$. The fundamental principle of this technology is based on the electrostatic forces for the production of nanofibers. High voltage is applied to a polymer solution and the sample collector to produce electric field jets supporting the formation of fibers through solvent evaporation during the process [222,223]. The use of the technique focuses on the main discussions intrinsically connected with the area; it is interpreted as an innovative, effective technique with low cost and versatility that 
can be applied in several industrial fields [220,224-226]. The electrified nanofibers have attracted the attention of enzyme engineering and biocatalysis, being considered a potential tool because of their numerous advantages: high surface area, multiple fixation points to the support, high porosity, interconnectivity, high thermal resistance, $\mathrm{pH}$ stability, and several solvents $[216,220,222,223,227]$. The process of immobilizing enzymes in electrified fibers usually promotes the retention and improvement of biological catalytic activity and allows for the easy separation of the enzyme from the proposed reaction environment $[216,223,224,228,229]$.

Note that the surface fixation process refers to the physical adsorption or fixation of enzymes in pure or functionalized nanofibrous supports chemically or physically, and encapsulation means electrospinning of the enzyme and the polymer mixture $[219,222,223,228,229]$. Electrofused nanofibers have a great potential to overcome dispersion problems, mass transfer limitation, and low recyclability and can be used as suitable supports for the immobilization of several enzymes [216,218,221]. In summary, the notoriety attributed to electrification as an innovative technique is directly connected with the qualification of nanofibers $[220,225,227,230]$. Aspects such as the diversity of polymers that can be electrophile, high porosity, and chemical interaction of the electrophile support give them a minimal impediment to mass transfer in addition to their industrial usability $[216,219,223,225,230]$. However, each enzyme interacts differently with the support, so when this technique is chosen, one should pay particular attention to the physical characteristics of the enzyme and the support, always looking at the congruence and adequacy of the size of the enzyme and the pore of the support $[216,219,220,223,227,230]$. Figure 5 shows how the process of enzyme immobilization by electrospinning occurs.

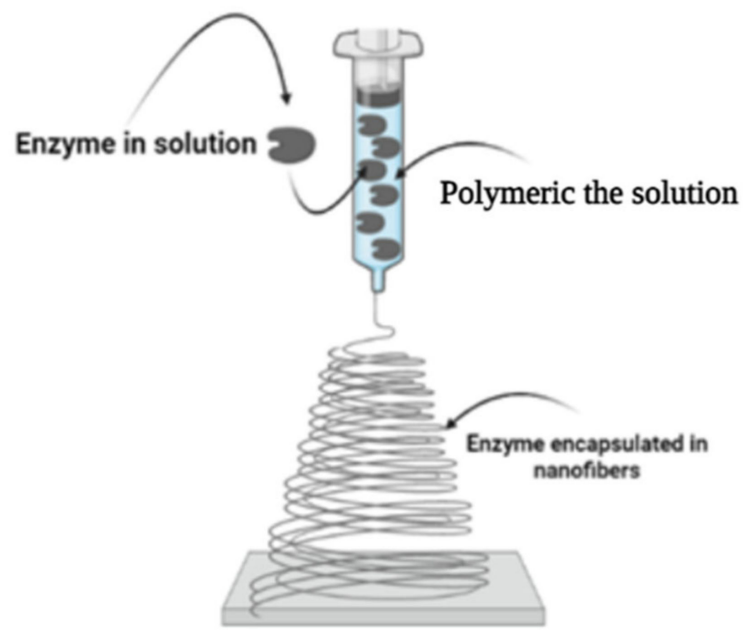

Figure 5. Electrospinning enzyme immobilization method. In this process, the enzyme is dispersed in the solution in which the process of physical/covalent adsorption and encapsulation of the enzyme in nanofibers occurs through the electrospinning process, producing a heterogeneous biocatalyst.

Several studies have reported different proposals to immobilize enzymes in electrophile nanofibers [216,219,223-228]. These proposals mainly include binding the enzyme on the surface of nanofibers and enzyme encapsulation [216,219,223,228].

In this sense, Kuang et al. (2020) [231] reported the development of lipases of Burkholderia cepacia (BCL)-SiO2 (NFM) nanofiber membrane bioreactors prepared through combined electrospinning and enzymatic immobilization strategies. The lipase loading capacity increased drastically, and a certain favoring in the thermal and solvent stability of the biocatalyst formed by electrospinning was noticed, highlighting the technique as efficient for this protocol. Activity remained above $80 \%$ after five cycles [231]. In contrast, Isik et al. (2019) [232] synthesized PVA $/ \mathrm{Zn}_{2}{ }^{+}$nanofibers using electrospinning and then successfully mobilized the lipase into electrospun nanofibers. The results obtained showed the efficiency of the protocol through the improvement of the immobilization parameters of the formed 
biocatalyst. Interpreting the immobilization results, the catalytic derivative formed had an increase in the stability properties of the enzyme, such as thermal stability, $\mathrm{pH}$ stability, and reusability. Furthermore, it is noteworthy that the immobilized nanoelectrospun biocatalyst protected $90 \%$ of the catalytic activity after 14 reuses [232]. This indicates that the recovery of heterogeneous biocatalysts formed using electrospinning protocols is desirable for applications in wastewater treatment industries, drug production, and the field of cosmetic production [231,232].

In summary, the immobilization method by electrospinning has proved to be a potential alternative to overcome several daily limitations resulting from the scarcity of natural resources to synthesize new enzyme immobilization matrices. In addition, the versatility of this method provides its wide industrial application.

\subsection{Electrospraying}

The electrospraying technique, popularly known as electrohydrodynamic atomization (EHDA), is a potential technology similar to electrospinning to synthesize polymeric nanoparticles or bioactive fiber-based materials used in various processes [233-235]. Classically, the electrospraying technique is defined as atomizing the liquid through electrical forces [236-239]. The fundamental difference between electrospraying and electrification is the alteration of the properties of the solution, such as solvent concentration, viscosity, and process parameters such as flow rate, distance from the needle tip to the collector, and, mainly, the voltage used $[236,237,240]$. Moreover, when the concentration of the solution is high, the Taylor cone jet is stabilized, and elongation occurs by the mechanism of whip instability. It is noteworthy that during the process of tailor cone jet formation in electrospraying, changes in parameters can result in the cleavage of the jet in drops, resulting in the formation of particles of different sizes and shapes $[234,236,240]$. This process forms micro- and nanoparticles with high loading power and regular particle size distribution $[233,234,236,237,239,240]$.

A few years ago, coaxial electrospraying emerged as an innovative technology for synthesizing products with two miscible or immiscible core and wall materials [233,238,239,241,242]. Coaxial electrospraying is a more convenient one-step method for manufacturing nanoparticles in dry form, thus expanding its industrial applications [233-238]. One of the main advantages of this technique for the immobilization of enzymes is the possibility of designing and adjusting the shape and size of nanoparticles only by modifying the experimental conditions $[233,238,239]$. This aspect reaffirms the potential of this technique for the enzyme stabilization process in solid matrices $[233,237,239,242]$. In this sense, electro-pulverized nanoparticles act as a support structure for enzyme immobilization [234,236-238]. A benefit of enzyme crosslinking for particles submitted to electrospraying is excellent residual activity justified by the considerable increase in surface area and porosity $[234,236,238,241,243]$. In addition, reducing the size of the carrier matter can also improve the efficiency of immobilized enzymes. Thus, the catalytic capacity of enzymes is usually optimized [235,238-240]. However, despite all these advantages mentioned above, there is a scarcity of studies related to this area specifically, to a large degree justified by its only recent discovery [235-238]. Figure 6 below shows the simple process of electrospraying enzyme immobilization.

Liu et al. (2018) [244] immobilized lipases on electrospray fibers with some reinforcement materials such as P(GMA-co-MA)-g-PEO (poly(glycidyl methacrylate-co-methyl acrylate)-g-polyethylene oxide). It is noteworthy that the activity and stability of the derivative were improved, and consequently, the derivative became more versatile, able to be applied in various fields. In summary, the researchers reported that the results showed that the immobilized lipase has good thermal stability, reusability, and stability in organic solvents. The good stabilities of the immobilized lipase revealed that the electrospray fibrous membrane $\mathrm{P}(\mathrm{GMA}-\mathrm{co}-\mathrm{MA})$-g-PEO is an exceptional carrier for enzyme immobilization [245]. 

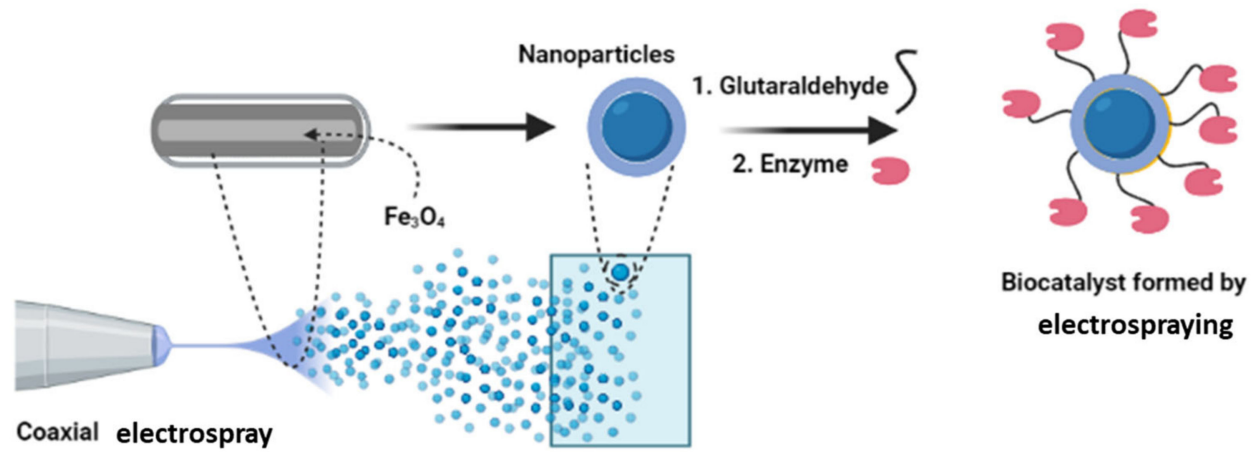

Figure 6. Electrospraying enzyme immobilization method. First, iron nanoparticles stop by electrospraying, then they are activated with glutaraldehyde, and then the enzymes bind to the electrospraying nanoparticles by physical/covalent adsorption or encapsulation depending on the size of the enzyme.

In summary, the electrospraying method has become increasingly recurrent in research because it presents advantages different from those commonly highlighted by other classical protocols of enzyme immobilization. In addition, both studies above present the versatility of enzyme immobilization in electroplated supports, perceiving the different areas in which the authors applied their biocatalysts. Despite the great potential of the electrospraying technique for immobilizing lipases and other enzymes, further studies must improve this strategy. It mainly concerns the reproducibility of scale-up methods, economic feasibility, and design of new equipment for the production of nanoparticles by electrospraying, making them competitive for industrial applications [246].

\subsection{Hybrid Nanoflowers}

Hybrid nanoflowers (UFHs) are compounds consisting of organic and inorganic components with a hierarchical three-dimensional nanostructure similar to a flower [247]. Since their inception, these materials have been desirable and desirable for various industry sectors due to their characteristic features such as rapid and eco-friendly synthesis [247-249]. Their high thermal stability, mechanical resistance, and wide surface area constitute their main advantages, enabling these matrices for enzyme immobilization $[247,250]$. The heterogeneous biocatalysts derived from these preparations are generally veritable and can be applied in several fields: biocatalysis, chemical, and biological analyses, synthesis of chemicals, treatment of pollutants, among many other possibilities [251-253].

It is noteworthy that the increase in the enzyme's thermal stability is usually one of the limiting factors for using free enzymes in high-impact industrial processes $[249,254,255]$. In addition to this aspect, there is usually an increase in enzyme tolerance by various reactional media, such as organic solvents, and also the primary foundation of immobilization facilitated reuse of the biocatalyst in several reactions cycles $[247,248,250]$. The synthesis of hybrid nanoflowers is usually straightforward, composed of a reaction of active organic enzymes/molecules and metal ions in aqueous phosphate buffer, usually at $\mathrm{pH} 7$ and $25^{\circ} \mathrm{C}$, generating a hierarchically structured compound with a wide surfaceto-volume ratio, retaining a large part of the biomolecules without severe mass transfer limitations $[249,250,256]$. The preparation typically takes three to five days. However, in a recent study using sonication as an accelerator mechanism, An et al. (2015) [253] reduced this time to just 5 minutes. Many authors used this method to confirm the proposed protocol's efficiency and efficacy [253,254,256-258]. Figure 7 shows how the process for enzyme immobilization by hybrid nanoflowers occurs: 


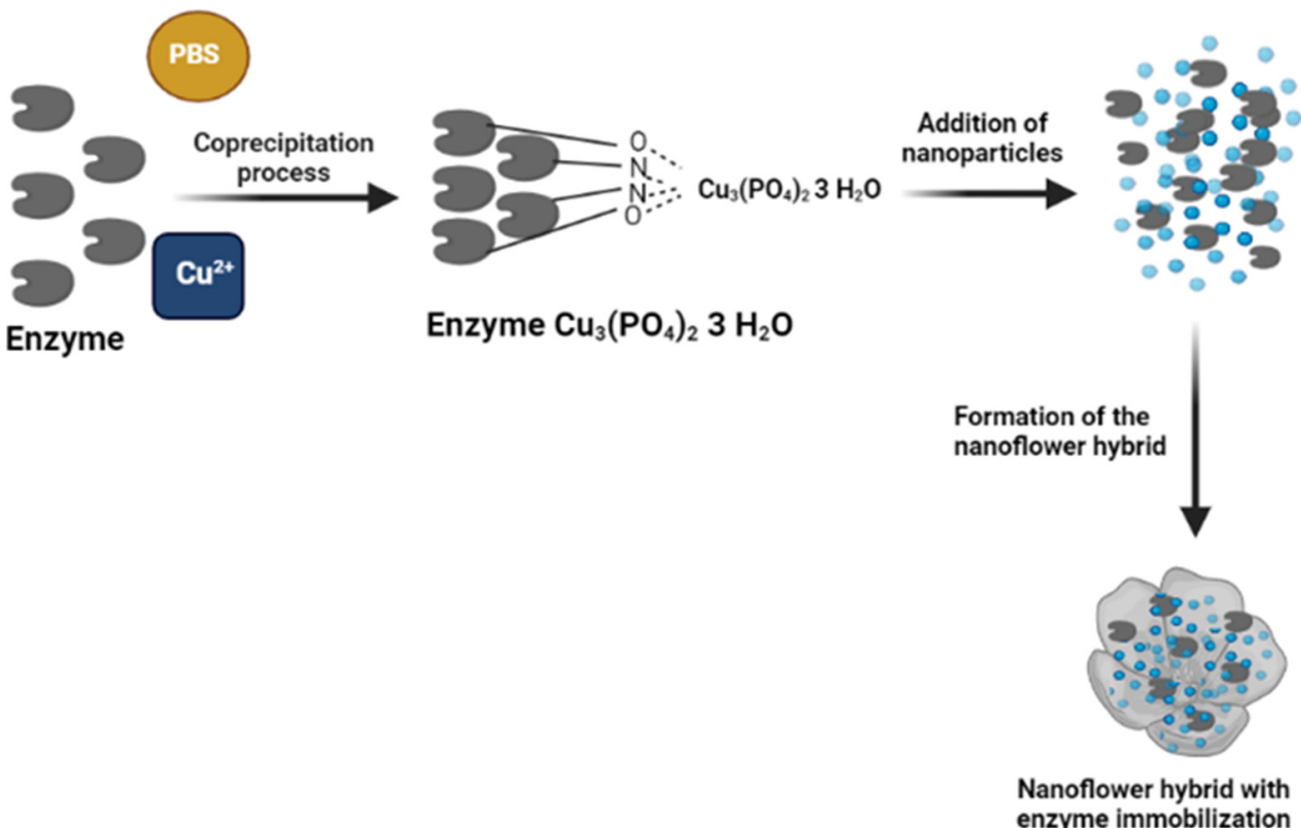

Figure 7. Hybrid nanoflowers enzyme immobilization method. First is the coprecipitation of enzymes using PBS and copper ions as an example of an inorganic particle. After coprecipitation, magnetic nanoparticles are usually added to the solution to facilitate separation and reuse. They form an enzymatic biocatalyst of magnetically responsive hybrid nanoflowers.

Li et al. (2020) [247] reported the effective production of lipase-inorganic hybrid nanoflowers (NF-lipase) using $\mathrm{Ca}_{3}\left(\mathrm{PO}_{4}\right)_{2}$ as the inorganic component and lipase from Aspergillus oryzae as the organic component. The generated biocatalyst was analyzed using physicochemical analyses that confirmed the immobilization of the lipase in the produced nanoflower. Furthermore, the catalytic derivative showed high catalytic activity, maintaining activity above $50 \%$ after seven consecutive reaction cycles. Furthermore, it is noteworthy that the HNF-lipase exhibited increased stability against high temperature and denaturants, obtaining good storage stability and reusability [259]. Liu et al. (2020) [260] immobilized the thermophilic lipase QLM from Alcaligenes sp. successfully in hybrid inorganic nanoflowers based on $\mathrm{Cu}_{3}\left(\mathrm{PO}_{4}\right)_{2}$ through biomimetic mineralization. The catalytic derivative showed high thermal stability, maintaining catalytic activity above $70 \%$ after eight reaction cycles at temperatures between $65{ }^{\circ} \mathrm{C}$ and $70{ }^{\circ} \mathrm{C}$ [260]. In these examples, the efficiency of this new immobilization strategy is noticeable, primarily when researchers aim mainly to maintain the catalytic activity at high temperatures.

The preparation of biocatalysts via an HNF-lipase requires a better understanding of their molecular interactions. Interactions of ions with lipases must be understood to modulate enzyme activity and increase stability. Thus, the controlled production of these enzymatic biocatalysts would be improved. Furthermore, enabling and reusing these biocatalysts in continuous and efficient processes is a challenge to overcome for industrial applications.

\subsection{Pickering Emulsion Enzyme Encapsulation}

The emulsion process in chemistry is characterized as a mixing of two or more liquids, in which one of them must be present in the form of microscopic droplets dispersed by the other liquid [261-263]. Emulsions are spontaneously synthesized. However, mechanical agitation, ultrasound, and other physical tools are used to accelerate the process [263-265]. It is worth remembering that there are several types of emulsions in chemistry, characterizing this technique as one of the most versatile; it can be applied in many fields such as the food industry, pharmaceuticals, and cosmetics [263,266,267]. 
Specifically, a Pickering emulsion makes use of solid particles used alone as stabilizers, which accumulate at the interface between two immiscible liquids and stabilize the droplets against coalescence [266-269]. The reactional process of heterogeneous catalysis has gained much attention due to several aspects such as product-particle facilitated separation, minimal particle toxicity, and high catalytic activity process [262,264,268,269]. In addition, current studies show the very high tolerance of this emulsion to organic reactional environments (hexane, methanol, acetonitrile, tetrahydrofuran, among others) $[262,263,265,269]$. To improve the understanding of the Pickering emulsion enzyme encapsulation method, Figure 8 explains each step in greater detail.

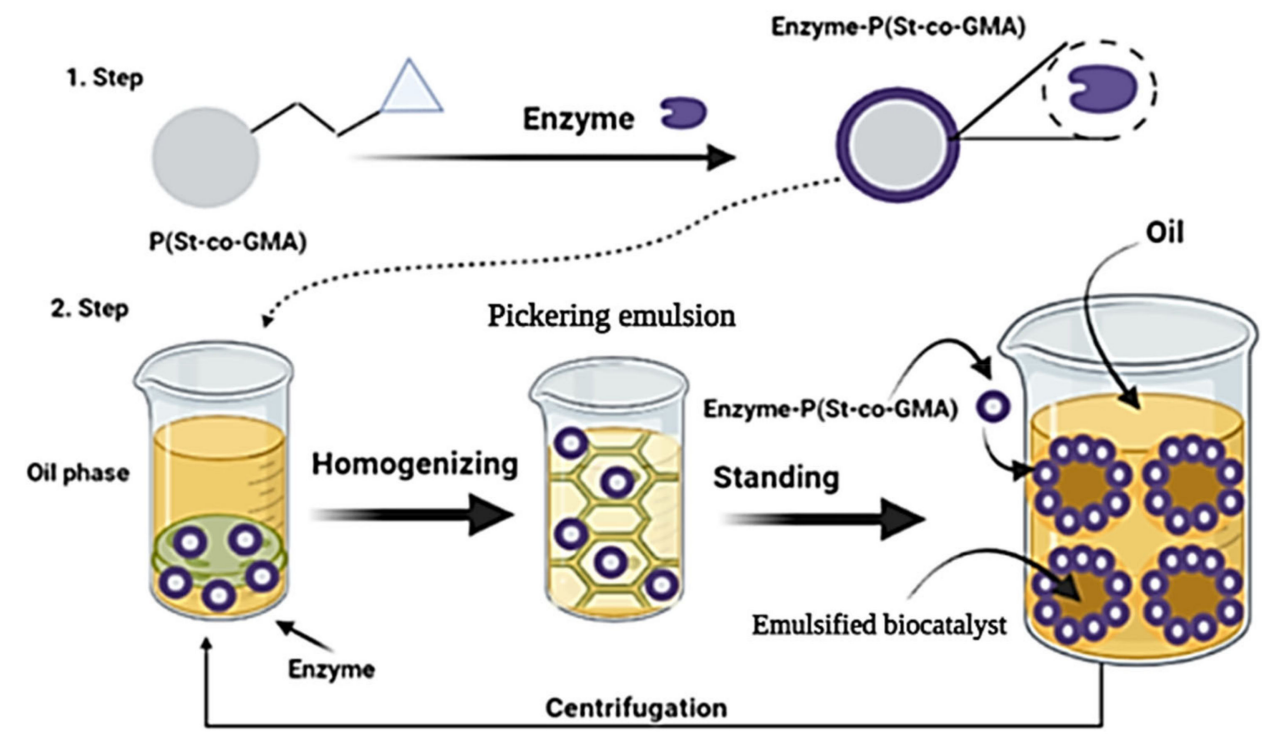

Figure 8. Enzyme-decorated nanoparticle-stabilized Pickering gel emulsion for biphasic biocatalysis or Pickering high internal phase emulsions (HIPEs). In step 1, an enzyme-decorated polymeric nanoparticle is prepared to stabilize oil-in-water HIPEs by emulsion copolymerization without a styrene surfactant and glycidyl methacrylate. Then, the second step is adding the Pickering gel system of the enzyme decorated in the nanoparticle. Then, the emulsion is homogenized to increase the interaction of the nanoparticle with the emulsion. Subsequently, standing occurs and finally forms an emulsified biocatalyst using the Pickering method.

In this perspective, the area of enzymatic biocatalysis has been very interested in this process, given the low costs of developing protocols and the high catalytic response offered by the emulsified catalytic derivative [264,269-271]. This vehemence comes from the large "oil-water" interface area that allows biphasic reaction systems to have high efficiency in optimizing hydrogenation, oxidation processes, and enzymatic reactions [269,270,272-275]. Wang et al. (2017) [268] presented a simple strategy for immobilization of the lipase of Candida sp. at the oil/water interface of Pickering emulsions via covalent enzyme coupling with CHO-JNPs for organic/aqueous biphasic catalysis [268]. Sun et al. (2020) [267] demonstrated a protocol similar to that of Wang et al. (2017) [268]. However, Sun et al. (2020) [267] performed the ultrasound-assisted process to optimize the immobilization process, in addition to having used the lipase from Candida rugosa (CRL) as an enzyme [267]. In this sense, Sun obtained a more active catalytic derivative with $177 \mathrm{mg} / \mathrm{g}$ of activity while Wang-only $23.3 \mathrm{U} / \mathrm{mL}$. In addition, Wang's derivative retained this activity further, maintaining the catalysis power at $88.6 \%$ after 10 cycles, while Sun maintained only $75 \%$ after nine reactional cycles $[267,268]$. That said, it is noticeable that ultrasound as an optimization tool in these circumstances is exceptional because it usually allows the enzyme to have more contact with the water/oil interface $[263,266,268,269,272,275]$.

Therefore, Jiang et al. (2020) [276] presented a new Pickering interfacial biological catalysis platform with efficient encapsulation of the lipase of Candida sp. composed of binary particles and high catalytic performance. The enzymatic derivative showed 
excellent stability, structural integrity, and exceptional reuse [276]. This approach has allowed overcoming one of the main limitations of Pickering emulsions, which is easy leaching. The authors highlight that the use of reinforcement particles is fundamental to improving the interaction of the enzyme with the emulsion interface, offering more significant surface area and greater affinity for the active functional groups of the emulsion with the inactive region of the enzyme $[266,268,276]$.

In summary, this new strategy of enzyme immobilization has gained increasing interest from large industries due to its low-cost processes and numerous additional advantages, prioritizing the latent possibility of its development on the industrial scale almost without operational limitations. The production of enzymatic lipase biocatalysts via Pickering emulsions needs to overcome some challenges. In this context, stability, activity, and durability must be improved. It will be possible to produce them within a large-scale, reproducible, and economically viable industrial application.

\subsection{Peptide-Guided Immobilization}

Enzyme immobilization aims to enhance the catalytic characteristics of these enzymes, and thus different immobilization methodologies are currently being developed [277]. Therefore, peptides are being applied in these processes to increase the efficiency of immobilization. These peptides have hydrophobic characteristics that allow their use in aqueous or polarized media and such media as oils or bio-solvents that do not feature polarization [278]. In addition, peptides can be modified as their side chains to define their hydrophobic and hydrophilic properties more specifically [279]. These modifications in the chains of a peptide guarantee its application on more substrates, regardless of its polarity [280]. In simulations and analysis, it was possible to verify that most peptides tend to present an $\alpha$-helical shape in nonaqueous (polarized) environments [281].

Another way to use peptides in enzyme immobilization would be to combine proteins with peptides, thus performing a specific and oriented binding appropriately [282]. This combination can preserve the enzyme's binding to the support and maintain its biological activity. Peptide-guided immobilization was used with the Escherichia coli biofilm as support and kept the catalytic properties of the enzymes unchanged [283]. In this case, a differential would be the possibility of undoing the connection when using low $\mathrm{pH}$ solutions, thus allowing the use of the materials in other future applications [284]. Figure 9 allows the visualization of peptide-guided immobilization at different $\mathrm{pH}$ levels.
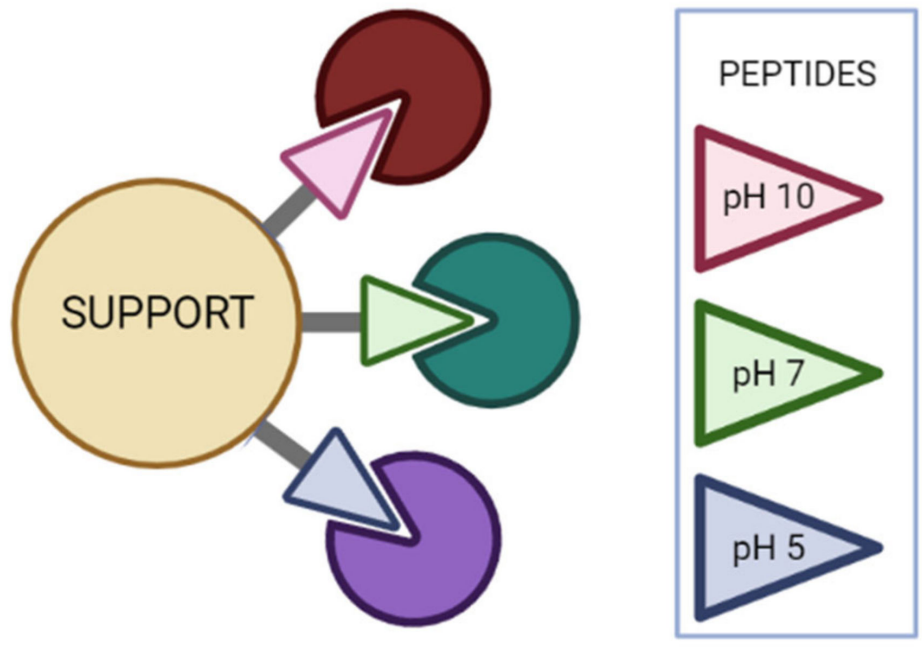

\section{ENZYMES}

Figure 9. Peptide-guided bonds where different enzymes are immobilized on the same support that has regions with different $\mathrm{pH}$. 
Such applications and characteristics presented by peptides and polypeptides reinforce that its application as a guide for enzymatic immobilization is possible. Furthermore, their properties adapt well to different environments. Therefore, studies with peptides resulted in more application possibilities and more efficient immobilization processes. One of the most promising strategies for lipase immobilization is the technique of using peptides. They can be obtained from different materials and have facilitating characteristics for immobilization systems, such as size and sequences. However, understanding the interaction mechanics between peptides and proteins in the immobilization process is necessary to obtain active and stable enzymatic biocatalysts. Optimizing these systems to make them economically competitive for the industry is another challenge to be overcome.

\section{Novel Carriers for Immobilization}

Several support materials of different origins can be used for enzyme immobilization. Many desirable characteristics influence the choice of enzyme carriers, like the functional groups and charge on the surface, homogeneous particle size, pore size distribution, high surface area, biocompatibility, low cost, inertness towards the enzyme and all the components of the reaction media, microbial resistance, thermal stability, and mechanical stability for continuous production in reactors [79,285-287]. Regarding enzyme immobilization, the carrier's surface functional groups and charges determine its interaction with the enzyme [288-290]. The surface area and porosity of the matrix are the parameters of influence on the amount of the enzyme that can be immobilized [291-293]. Recent research into new materials has contributed to new supports for immobilizing lipases with better features. As shown in Figure 10, these new materials include waste biomaterials, nanomaterials, synthetic resins, mesoporous and electrospun materials. Table 1 also contains detailed information from recent studies [81,294-296].

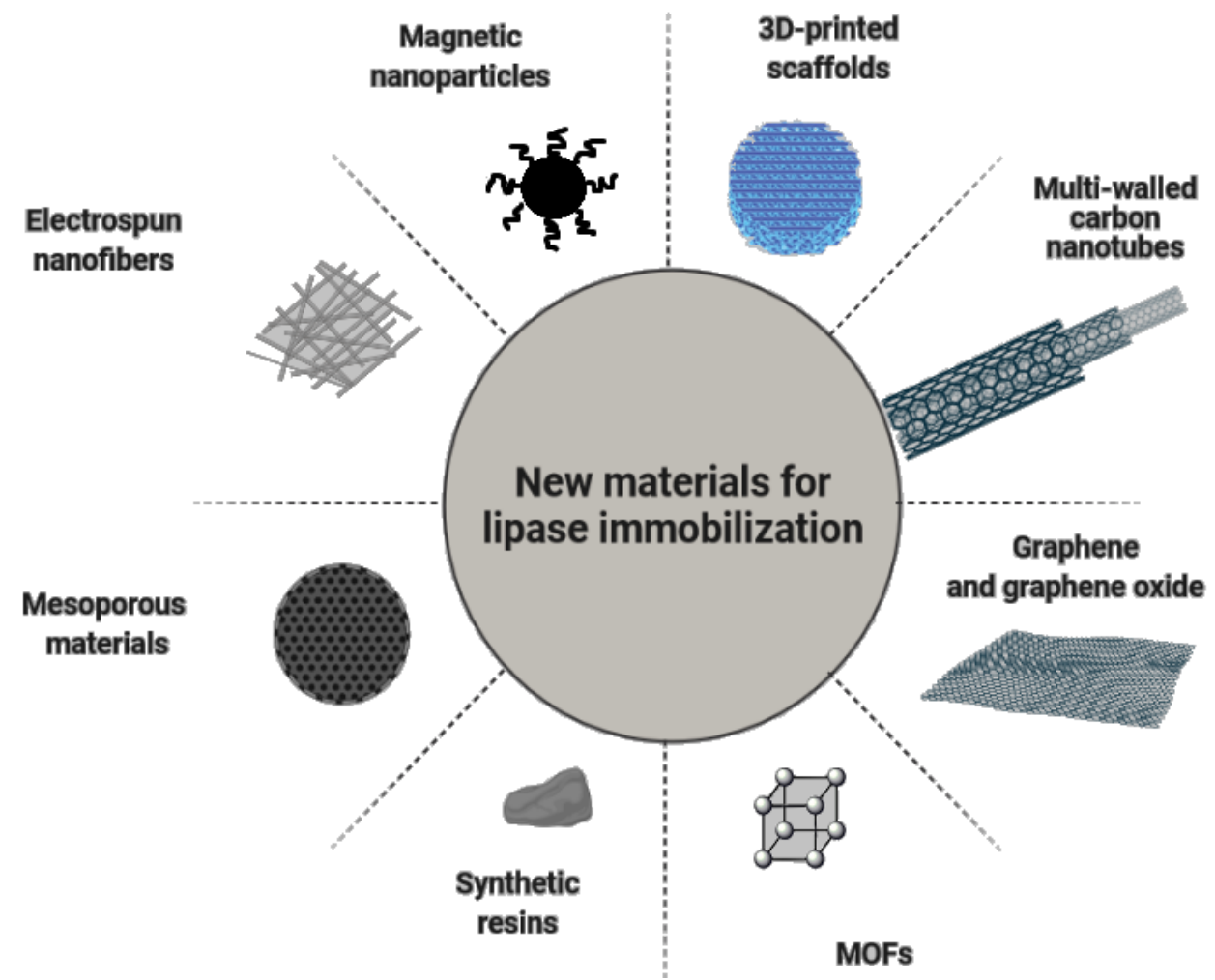

Figure 10. Novel materials used for lipase immobilization. 
Table 1. Novel research in lipase immobilization.

\begin{tabular}{|c|c|c|c|c|}
\hline Support & Lipase Source & Application & $\begin{array}{l}\text { Immobilization } \\
\text { Technique }\end{array}$ & Ref. \\
\hline $\begin{array}{c}\text { Virus-like mesoporous } \\
\text { organosilica nanoparticles }\end{array}$ & $\begin{array}{l}\text { Lipase B from } \\
\text { Candida antarctica }\end{array}$ & $\begin{array}{l}\text { Synthesis of levulinate } \\
\text { esters }\end{array}$ & Covalent bonding & [297] \\
\hline $\begin{array}{l}\text { Lifetech }{ }^{\mathrm{TM}} \\
\text { methacrylic } \\
\text { synthetic resins }\end{array}$ & Thermomyces lanuginosus & Biodiesel synthesis & $\begin{array}{l}\text { Physical } \\
\text { adsorption }\end{array}$ & [298] \\
\hline $\begin{array}{l}\text { MIL-101(Cr) } \\
\text { MOFs }\end{array}$ & Candida rugosa & $\begin{array}{l}\text { Hydrolysis of } p \text {-nitrophenyl } \\
\text { palmitate }\end{array}$ & Covalent bonding & [299] \\
\hline $\begin{array}{l}\text { Chitosan-mesoporous silica } \\
\text { hybrid nanomaterials }\end{array}$ & Porcine pancreatic PPL & Triacetin hydrolysis & Covalent bonding & {$[300]$} \\
\hline $\begin{array}{l}\text { Magnetic multiwalled } \\
\text { carbon nanotubes }\end{array}$ & Candida rugosa & Synthesis of fruit flavors & $\begin{array}{l}\text { Covalent } \\
\text { bonding }\end{array}$ & [301] \\
\hline $\begin{array}{l}\text { 3D-printed carbon } \\
\text { fiber-reinforced polylactic } \\
\text { acid scaffolds }\end{array}$ & Burkholderia ambifaria & $\begin{array}{l}\text { Hydrolysis of } p \text {-nitrophenyl } \\
\text { palmitate }\end{array}$ & Adsorption & [203] \\
\hline $\begin{array}{l}\text { Inorganic hybrid nanosheets on } \\
\text { sulfonated macroporous resins }\end{array}$ & Candida rugosa & $\begin{array}{l}\text { Hydrolysis of the olive } \\
\text { oil emulsion }\end{array}$ & Encapsulation & [302] \\
\hline $\begin{array}{c}\text { Nanocellulose-fused } \\
\text { polypyrrole/graphene oxide } \\
\text { nanocomposites }\end{array}$ & Candida rugosa & Synthesis of fruit flavors & Adsorption & [303] \\
\hline $\begin{array}{c}\text { Poly(carboxybetaine } \\
\text { methacrylate)-grafted silica } \\
\text { nanoparticles }\end{array}$ & Candida rugosa & $\begin{array}{l}\text { Hydrolysis of } p \text {-nitrophenyl } \\
\text { acetate }\end{array}$ & Covalent bonding & [304] \\
\hline Spherelike bacterial cellulose & Rhizopus chinensis & $\begin{array}{l}\text { Hydrolysis of the olive oil } \\
\text { emulsion }\end{array}$ & $\begin{array}{l}\text { Covalent bonding and } \\
\text { physical adsorption }\end{array}$ & [305] \\
\hline $\begin{array}{l}\text { Electrospun nanofibrous } \\
\text { membranes containing epoxy } \\
\text { groups and a hydrophilic } \\
\text { polyethylene oxide chain }\end{array}$ & $\begin{array}{l}\text { Lipase B from } \\
\text { Candida antarctica }\end{array}$ & Hydrolysis of olive oil & Covalent bonding & [244] \\
\hline Pyrolyzed sugar industry waste & Aspergillus sp. lipase & $\begin{array}{l}\text { Synthesis of 2-phenylethyl } \\
\text { butanoate }\end{array}$ & Adsorption & [306] \\
\hline $\begin{array}{l}\text { Octyl Sepharose crosslinked } \\
\text { with dextran } \\
\text { aldehyde polymers }\end{array}$ & $\begin{array}{c}\text { Thermomyces lanuginosus, } \\
\text { Rhizomucor miehiei, and } \\
\text { lipase B from } \\
\text { Candida antarctica }\end{array}$ & $\begin{array}{l}\text { Hydrolysis of } p \text {-nitrophenyl } \\
\text { butyrate }\end{array}$ & Covalent bonding & [307] \\
\hline Colloidal lignin particles & $\begin{array}{l}\text { Lipase } \mathrm{M} \text { from } M u c o r \\
\text { javanicus }\end{array}$ & Synthesis of butyl butyrate & Entrapment & [308] \\
\hline $\begin{array}{l}\text { Chitosan/nanocellulose } \\
\text { biocomposites }\end{array}$ & Candida rugosa & Synthesis of butyl butyrate & Covalent bonding & [309] \\
\hline Magnetic rice straws & Thermomyces lanuginosus & Synthesis of biodiesel & Covalent bonding & [310] \\
\hline $\begin{array}{l}\text { Diethylenetriamine-modified } \\
\text { magnetic cellulose beads }\end{array}$ & $\begin{array}{c}\text { Lipase B from Candida } \\
\text { antarctica }\end{array}$ & Synthesis of biodiesel & Covalent bonding & [311] \\
\hline Chitosan-chitin nanowhiskers & Rhizomucor miehei & Synthesis of eugenyl benzoate & Covalent bonding & [312] \\
\hline
\end{tabular}

Biopolymers can offer low cost, easy modification, high surface area, and various functional groups to stabilize lipase conformation [286,294]. As for drawbacks, it can be mentioned that their poor mechanical stabilities often make them unsuitable for industrial applications in bioreactors $[313,314]$. Chitosan, a trending biopolymer, also has low chemical and long-term stability [294]. The problems of enzyme leaching and stability of biopolymers have been addressed by using crosslinking agents and by the combinations of biopolymers to produce biocomposites [315,316]. The use of crosslinking agents requires attention to the possible adverse effects on lipase conformation, which can cause loss of activity. Concerning the formulation of biocomposites for lipase carriers, it is necessary to be careful with the produced biocomposites' hydrophilicity since it can also reduce the activity of the biocatalyst [317]. Current research often identifies new crosslinking agents and biocomposites that have properties superior to the existing materials $[28,318,319]$.

Biopolymers and biocomposites are used to produce different types of lipase matrices, conjugated or not, with a broad range of ligands of distinguished properties and nature, as mentioned in recent studies: membranes, resins, nanofibers, beads, nanoparticles, nanotubes, scaffolds, colloidal particles, and nanowhiskers [203,244,298,305,308,309,312]. In the study of Elias et al. (2018) [309], the biocatalyst consisting of a biopolymer carrier of nanocellulose/chitosan was prepared by extraction of nanocellulose from palm oil frond leaves, followed by consecutive crosslinking with chitosan and the Candida rugosa lipase, 
both using glutaraldehyde as crosslinking agent $[309,320]$. The prepared biocatalyst was applied in butyl butyrate synthesis, showing good thermal stability, and retained about $50 \%$ of its initial activity through seven consecutive recycles [309].

In another study, spatially confined biocatalysts upon self-assembly and drying-driven aggregation of Lipase $\mathrm{M}$ from Mucor javanicus cationic lignin nanosphere (c-CLP) complexes were prepared in the calcium alginate hydrogel [308]. This innovative procedure showed retained activity superior to the commercially available immobilized biocatalysts in the same conditions in butyl butyrate synthesis [308].

Another possible strategy is to incorporate inorganic materials to produce hybrid biocatalysts with unique properties [297,300,303,310,311]. Similarly, inorganic materials can be conjugated with organic or inorganic substances to produce other hybrid biocatalysts, as mentioned for many kinds of nanomaterials, metal-organic frameworks, mesoporous and ceramic materials [81,295,296,299,301,302,304].

In the work of Jiang et al. (2019) [297], a novel matrix for lipase immobilization was produced [297], hydrophobic virus-like organosilica nanoparticles (VOSNs) with a spherical core formed by mesoporous organosilica surrounded by epitaxial perpendicular nanotubes. They were made using the epitaxial growth method with hexadecyl trimethyl ammonium bromide as a template (CTAB) and tetraethyl orthosilicate (TEOS) and 1,2-bis(triethoxysilyl)ethane (BTSE) as silica sources. In a typical synthesis, CTAB was dispersed in deionized water under stirring. Then, an aqueous sodium hydroxide solution was added to the water solution and stirred for two hours at $60^{\circ} \mathrm{C}$. After that, a solution of TEOS and BTSE in cyclohexane was added dropwise. The reaction was continued by stirring the mixture at $60{ }^{\circ} \mathrm{C}$ for forty-eight hours. The product was collected by centrifugation, washed several times, and dispersed in acetone for refluxing treatment at $80^{\circ} \mathrm{C}$ for thirty-six hours to remove the CTAB template. After that, the surface was modified by 3-aminopropyl triethoxysilane (APTES) activated with glutaraldehyde and covalently bonded with lipase B from Candida antarctica. The prepared biocatalyst exhibited suitable $\mathrm{pH}$, thermal, organic, and storage stability. It was also demonstrated that the prepared biocatalyst exhibited superior reusability compared with free and immobilized lipases in virus-like silica nanoparticles [297].

Zare et al. (2018) [299] studied the effect of different chemical modifications of the MOF chromium terephthalate (MIL-101(Cr)) for immobilization of the Candida rugosa lipase [299]. Amino, trichlorotriazine amino, and glutaraldehyde amino were the groups added to the carrier surface, and the last two showed higher $\mathrm{pH}$, thermal, and storage stability, although all the preparations significantly lost activity in the reusability tests. According to the authors, these results were related to the biocatalyst contamination by the substrate, meaning that the biocatalyst could potentially use other types of substrates [299].

For 3D-printed materials, the fused deposition modeling (FDM) technology is based on extrudable thermoplastics, having the advantages of being low-cost and straightforward. In addition, the used fibers are cheap and easy to recycle, therefore reducing the operational costs [321]. In the work of Ye et al. (2019) [203], carbon fiber-reinforced polylactic acid 3D-printed scaffolds of different structural shapes were used to create integrated reactors carrying four types of enzymes including the Burkholderia ambifaria lipase, showing great recovery activity [203].

\section{Concluding Remarks}

Nanotechnology is occupying even more space in biocatalysis. This tool makes it possible to create carriers with specific features to improve operational stability, immobilization, and reaction yields. Still, it is necessary to reduce biocatalyst production costs, which are the main issue for their industrial applications. The use of waste materials is an exciting alternative since they are cheap and meet the growing environmental needs of the market. Other trending research focuses on genetic manipulation of lipases, co-immobilizing multiple lipases on the same matrix, and hybrid materials. Those increase process complexity and costs and can be further employed for the industrial use of immobilized lipases. 
As for new immobilization techniques, it is essential to emphasize that the choice of the method, support, and enzyme directly influences the process and is dependent on several factors. The various examples cited throughout the work demonstrate the results obtained by several researchers from the use of different conditions, involving not only these three factors but many others (temperature, $\mathrm{pH}$, reaction time). For the choice of lipase, it is essential to know the factors that influence its activity and the desired characteristics for its final application. At the same time, in choosing the method, it is essential to consider issues such as regeneration and deactivation of the enzyme, the cost of the process, and the toxicity of the reagents.

Author Contributions: Writing—original draft preparation, F.T.T.C., A.L.G.C., F.S.N. and J.C.S.d.S.; writing-review and editing, F.T.T.C., J.C.S.d.S. and I.G.d.S. All authors have read and agreed to the published version of the manuscript.

Funding: Conselho Nacional de Desenvolvimento Científico e Tecnológico (CNPq, project number 311062/2019-9).

Acknowledgments: We gratefully acknowledge the financial support of the following Brazilian Agencies for Scientific and Technological Development: Fundação Cearense de Apoio ao Desenvolvimento Científico e Tecnológico (FUNCAP), Conselho Nacional de Desenvolvimento Científico e Tecnológico (CNPq), and Coordenação de Aperfeiçoamento de Ensino Superior (CAPES) (finance code 001).

Conflicts of Interest: The authors declare no conflict of interest.

\section{References}

1. Bilal, M.; Iqbal, H.M.; Hu, H.; Wang, W.; Zhang, X. Metabolic engineering and enzyme-mediated processing: A biotechnological venture towards biofuel production-A review. Renew. Sustain. Energy Rev. 2018, 82, 436-447. [CrossRef]

2. Roy, A.; Bharadvaja, N. Biotechnological approaches for the production of pharmaceutically important compound: Plumbagin. Curr. Pharm. Biotechnol. 2018, 19, 372-381. [CrossRef] [PubMed]

3. Silveira, B.M.P.; Barcelos, M.C.S.; Vespermann, K.A.C.; Pelissari, F.M.; Molina, G. An overview of biotechnological processes in the food industry. In Bioprocessing for Biomolecules Production; John Wiley \& Sons, Ltd.: Chichester, UK, 2019; pp. 1-19.

4. Ashrafi, A.M.; Sýs, M.; Sedláčková, E.; Farag, A.S.; Adam, V.; Přibyl, J.; Richtera, L.; Sýs, A. Application of the enzymatic electrochemical biosensors for monitoring non-competitive inhibition of enzyme activity by heavy metals. Sensors 2019, 19, 2939. [CrossRef]

5. Mariz, B.d.P.; Carvalho, S.; Batalha, I.L.; Pina, A.S. Artificial enzymes bringing together computational design and directed evolution. Org. Biomol. Chem. 2021, 19, 1915-1925. [CrossRef] [PubMed]

6. $\quad$ Rodrigues, R.; Virgen-Ortíz, J.J.; dos Santos, J.C.; Berenguer-Murcia, A.; Alcantara, A.R.; Barbosa, O.; Ortiz, C.; FernandezLafuente, R. Immobilization of lipases on hydrophobic supports: Immobilization mechanism, advantages, problems, and solutions. Biotechnol. Adv. 2019, 37, 746-770. [CrossRef]

7. Schmid-Dannert, C.; López-Gallego, F. Advances and opportunities for the design of self-sufficient and spatially organized cell-free biocatalytic systems. Curr. Opin. Chem. Biol. 2018, 49, 97-104. [CrossRef]

8. Schmieg, B.; Döbber, J.; Kirschhöfer, F.; Pohl, M.; Franzreb, M. Advantages of hydrogel-based 3D-printed enzyme reactors and their limitations for biocatalysis. Front. Bioeng. Biotechnol. 2019, 6, 211. [CrossRef]

9. Bolina, I.C.A.; Gomes, R.A.B.; Mendes, A.A. Biolubricant production from several oleaginous feedstocks using lipases as catalysts: Current scenario and future perspectives. BioEnergy Res. 2021, 1-19. [CrossRef]

10. Pohanka, M. Biosensors and bioassays based on lipases, principles and applications: A review. Molecules 2019, 24, 616. [CrossRef]

11. Reis, P.; Holmberg, K.; Watzke, H.; Leser, M.; Miller, R. Lipases at interfaces: A review. Adv. Colloid Interface Sci. 2009, 147-148, 237-250. [CrossRef] [PubMed]

12. Melani, N.; Tambourgi, E.B.; Silveira, E. Lipases: From production to applications. Sep. Purif. Rev. 2019, 49, 143-158. [CrossRef]

13. Valério, R.B.R.; Cavalcante, A.L.G.; Mota, G.F.; de Sousa, I.G.; da Silva Souza, J.E.; Cavalcante, F.T.T.; de Aguiar Falcão, I.R.; da Silva Moreira, K. Understanding the biocatalytic potential of lipase from rhizopus chinensis. Biointerface Res. Appl. Chem. 2021, 12, 4230-4260. [CrossRef]

14. Jaeger, K.-E.; Eggert, T. Lipases for biotechnology. Curr. Opin. Biotechnol. 2002, 13, 390-397. [CrossRef]

15. Schmid, R.D.; Verger, R. Lipases: Interfacial enzymes with attractive applications. Angew. Chem. Int. Ed. 1998, 37, 1608-1633. [CrossRef]

16. Verger, R. 'Interfacial activation' of lipases: Facts and artifacts. Trends Biotechnol. 1997, 15, 32-38. [CrossRef]

17. Anderson, E.M.; Larsson, K.M.; Kirk, O. One biocatalyst-many applications: The use of candida antarctica b-lipase in organic synthesis. Biocatal. Biotransform. 1998, 16, 181-204. [CrossRef] 
18. Reetz, M.T. Biocatalysis in organic chemistry and biotechnology: Past, present, and future. J. Am. Chem. Soc. 2013, 135, 12480-12496. [CrossRef] [PubMed]

19. Reetz, M.T. Lipases as practical biocatalysts. Curr. Opin. Chem. Biol. 2002, 6, 145-150. [CrossRef]

20. Kublicki, M.; Koszelewski, D.; Brodzka, A.; Ostaszewski, R. Wheat germ lipase: Isolation, purification and applications. Crit. Rev. Biotechnol. 2021, 1-17. [CrossRef] [PubMed]

21. Sarmah, N.; Revathi, D.; Sheelu, G.; Rani, K.Y.; Sridhar, S.; Mehtab, V.; Sumana, C. Recent advances on sources and industrial applications of lipases. Biotechnol. Prog. 2017, 34, 5-28. [CrossRef]

22. Miguez, J.P.; Gama, R.S.; Bolina, I.C.; de Melo, C.C.; Cordeiro, M.R.; Hirata, D.B.; Mendes, A.A. Enzymatic synthesis optimization of a cosmetic ester catalyzed by a homemade biocatalyst prepared via physical adsorption of lipase on amino-functionalized rice husk silica. Chem. Eng. Res. Des. 2018, 139, 296-308. [CrossRef]

23. Monteiro, R.R.; Arana-Peña, S.; da Rocha, T.N.; Miranda, L.P.; Berenguer-Murcia, Á.; Tardioli, P.W.; dos Santos, J.C.; FernandezLafuente, R. Liquid lipase preparations designed for industrial production of biodiesel. Is it really an optimal solution? Renew. Energy 2020, 164, 1566-1587. [CrossRef]

24. Moreira, K.S.; Júnior, L.S.M.; Monteiro, R.R.C.; De Oliveira, A.L.B.; Valle, C.P.; Freire, T.M.; Fechine, P.B.A.; De Souza, M.C.M.; Fernandez-Lorente, G.; Guisan, J.M.; et al. Optimization of the production of enzymatic biodiesel from residual babassu oil (Orbignya sp.) via RSM. Catalysts 2020, 10, 414. [CrossRef]

25. Cavalcante, F.T.T.; Neto, F.S.; Falcão, I.R.D.A.; Souza, J.E.D.S.; Junior, L.S.D.M.; Sousa, P.D.S.; Rocha, T.G.; de Sousa, I.G.; Gomes, P.H.D.L.; de Souza, M.C.M.; et al. Opportunities for improving biodiesel production via lipase catalysis. Fuel 2020, $288,119577$. [CrossRef]

26. Lima, G.V.; da Silva, M.R.; Fonseca, T.D.S.; de Lima, L.B.; Oliveira, M.D.C.F.D.; de Lemos, T.L.G.; Zampieri, D.; dos Santos, J.C.S.; Rios, N.S.; Gonçalves, L.R.B.; et al. Chemoenzymatic synthesis of (S)-Pindolol using lipases. Appl. Catal. A Gen. 2017, 546, 7-14. [CrossRef]

27. Coelho, A.L.S.; Orlandelli, R.C. Immobilized microbial lipases in the food industry: A systematic literature review. Crit. Rev. Food Sci. Nutr. 2020, 61, 1689-1703. [CrossRef] [PubMed]

28. Quayson, E.; Amoah, J.; Hama, S.; Kondo, A.; Ogino, C. Immobilized lipases for biodiesel production: Current and future greening opportunities. Renew. Sustain. Energy Rev. 2020, 134, 110355. [CrossRef]

29. Contesini, F.J.; Davanço, M.G.; Borin, G.P.; Vanegas, K.G.; Cirino, J.P.G.; De Melo, R.R.; Mortensen, U.H.; Hildén, K.; Campos, D.R.; Carvalho, P.D.O. Advances in recombinant lipases: Production, engineering, immobilization and application in the pharmaceutical industry. Catalysts 2020, 10, 1032. [CrossRef]

30. Lima, P.J.M.; da Silva, R.M.; Neto, C.A.C.G.; e Silva, N.C.G.; Souza, J.E.D.S.; Nunes, Y.L.; dos Santos, J.C.S. An overview on the conversion of glycerol to value-added industrial products via chemical and biochemical routes. Biotechnol. Appl. Biochem. 2021. [CrossRef]

31. Rocha, T.G.; Gomes, P.H.D.L.; de Souza, M.C.M.; Monteiro, R.R.C.; dos Santos, J.C.S. Lipase cocktail for optimized biodiesel production of free fatty acids from residual chicken oil. Catal. Lett. 2020, 151, 1155-1166. [CrossRef]

32. Souza, J.E.S.; Monteiro, R.R.C.; Rocha, T.G.; Moreira, K.S.; Cavalcante, F.T.T.; Braz, A.K.D.S.; de Souza, M.C.M.; dos Santos, J.C.S. Sonohydrolysis using an enzymatic cocktail in the preparation of free fatty acid. 3 Biotech 2020, 10, 1-10. [CrossRef]

33. De Souza, T.C.; Fonseca, T.D.S.; Silva, J.D.S.; Lima, P.J.M.; Neto, C.A.C.G.; Monteiro, R.R.C.; Rocha, M.V.P.; De Mattos, M.C.; Dos Santos, J.C.S.; Gonçalves, L.R.B. Modulation of lipase B from Candida antarctica properties via covalent immobilization on eco-friendly support for enzymatic kinetic resolution of rac-indanyl acetate. Bioprocess Biosyst. Eng. 2020, 43, 2253-2268. [CrossRef]

34. Pinheiro, M.P.; Monteiro, R.R.; Silva, F.F.; Lemos, T.L.; Fernandez-Lafuente, R.; Gonçalves, L.R.; dos Santos, J.C. Modulation of Lecitase properties via immobilization on differently activated Immobead-350: Stabilization and inversion of enantiospecificity. Process. Biochem. 2019, 87, 128-137. [CrossRef]

35. Filho, D.G.; Silva, A.G.; Guidini, C.Z. Lipases: Sources, immobilization methods, and industrial applications. Appl. Microbiol. Biotechnol. 2019, 103, 7399-7423. [CrossRef]

36. Paulino, B.N.; Pessôa, M.G.; Molina, G.; Neto, A.A.K.; Oliveira, J.V.C.; Mano, M.C.R.; Pastore, G.M. Biotechnological production of value-added compounds by ustilaginomycetous yeasts. Appl. Microbiol. Biotechnol. 2017, 101, 7789-7809. [CrossRef]

37. Maldonado, R.R. A review on geotrichum lipases: Production, purification, immobilization and applications. Chem. Biochem. Eng. Q. 2017, 30, 439-454. [CrossRef]

38. Riegler-Berket, L.; Leitmeier, A.; Aschauer, P.; Dreveny, I.; Oberer, M. Identification of lipases with activity towards monoacylglycerol by criterion of conserved cap architectures. Biochim. Biophys. Acta Mol. Cell Biol. Lipids 2018, 1863, 679-687. [CrossRef] [PubMed]

39. Bauer, T.L.; Buchholz, P.C.F.; Pleiss, J. The modular structure of $\alpha / \beta$-hydrolases. FEBS J. 2019, 287, 1035-1053. [CrossRef] [PubMed]

40. Rios, N.; Pinheiro, B.; Pinheiro, M.P.; Bezerra, R.M.; dos Santos, J.C.S.; Gonçalves, L.R.B. Biotechnological potential of lipases from pseudomonas: Sources, properties and applications. Process. Biochem. 2018, 75, 99-120. [CrossRef]

41. Cheng, C.; Jiang, T.; Wu, Y.; Cui, L.; Qin, S.; He, B. Elucidation of lid open and orientation of lipase activated in interfacial activation by amphiphilic environment. Int. J. Biol. Macromol. 2018, 119, 1211-1217. [CrossRef] [PubMed] 
42. Hama, S.; Noda, H.; Kondo, A. How lipase technology contributes to evolution of biodiesel production using multiple feedstocks. Curr. Opin. Biotechnol. 2018, 50, 57-64. [CrossRef] [PubMed]

43. Hao, Y.; Zheng, X.; Zhang, X.; Zhang, K.; Lin, Y.; Liang, S. Combined strategies for engineering a novel whole-cell biocatalyst of Candida rugosa lipase with improved characteristics. Biochem. Eng. J. 2019, 151. [CrossRef]

44. Bresolin, D.; Estrella, A.S.; Da Silva, J.R.P.; Valerio, A.; Sayer, C.; de Araujo, P.H.H.; De Oliveira, D. Synthesis of a green polyurethane foam from a biopolyol obtained by enzymatic glycerolysis and its use for immobilization of lipase NS. Bioprocess. Biosyst. Eng. 2018, 42, 213-222. [CrossRef]

45. Zhong, L.; Feng, Y.; Wang, G.; Wang, Z.; Bilal, M.; Lv, H.; Jia, S.; Cui, J. Production and use of immobilized lipases in/on nanomaterials: A review from the waste to biodiesel production. Int. J. Biol. Macromol. 2020, 152, 207-222. [CrossRef]

46. Lv, L.; Dai, L.; Du, W.; Liu, D. Progress in enzymatic biodiesel production and commercialization. Processes 2021, 9, 355. [CrossRef]

47. Bezerra, R.M.; Monteiro, R.R.C.; Neto, D.M.A.; da Silva, F.F.; de Paula, R.; de Lemos, T.L.; Fechine, P.B.; Correa, M.; Bohn, F.; Gonçalves, L.R.; et al. A new heterofunctional support for enzyme immobilization: PEI functionalized $\mathrm{Fe}_{3} \mathrm{O}_{4} \mathrm{MNPs}$ activated with divinyl sulfone. Application in the immobilization of lipase from thermomyces lanuginosus. Enzym. Microb. Technol. 2020, 138, 109560. [CrossRef]

48. Melo, A.D.Q.; Silva, F.F.M.; Dos Santos, J.C.S.; Fernández-Lafuente, R.; Lemos, T.L.G.; Filho, F.A.D. Synthesis of benzyl acetate catalyzed by lipase immobilized in nontoxic chitosan-polyphosphate beads. Molecules 2017, 22, 2165. [CrossRef]

49. Bonazza, H.L.; Manzo, R.M.; Mammarella, E.J.; Dos Santos, J.C.S. Operational and thermal stability analysis of thermomyces lanuginosus lipase covalently immobilized onto modified chitosan supports. Appl. Biochem. Biotechnol. 2017, 184, s12010-s12017. [CrossRef]

50. Villalba, M.; Verdasco-Martín, C.M.; dos Santos, J.C.S.; Fernandez-Lafuente, R.; Otero, C. Operational stabilities of different chemical derivatives of Novozym 435 in an alcoholysis reaction. Enzym. Microb. Technol. 2016, 90, 35-44. [CrossRef]

51. Garcia-Galan, C.; dos Santos, J.C.; Barbosa, O.; Torres, R.; Pereira, E.B.; Corberan, V.C.; Gonçalves, L.R.; Fernandez-Lafuente, R. Tuning of Lecitase features via solid-phase chemical modification: Effect of the immobilization protocol. Process. Biochem. 2014, 49, 604-616. [CrossRef]

52. Dos Santos, J.C.S.; Garcia-Galan, C.; Rodrigues, R.; Ana, H.B.D.S.; Goncalves, L.R.B.; Fernandez-Lafuente, R. Improving the catalytic properties of immobilized Lecitase via physical coating with ionic polymers. Enzym. Microb. Technol. 2014, 60, 1-8. [CrossRef]

53. Da Fonseca, A.M.; Colares, R.P.; De Oliveira, M.M.; De Souza, M.C.M.; Monteiro, R.R.C.; Araújo, R.D.S.; Amorim, A.V.; Dos Santos, J.C.S.; Alcócer, J.C.A.; Pinto, O.R.D.O. Enzymatic biocatalyst using enzymes from pineapple (Ananas comosus) peel immobilized in hydrogel beads. Rev. Eletrônica Gestão Educ. Tecnol. Ambient. 2019, 23, 32. [CrossRef]

54. Monteiro, R.; Dos Santos, J.; Alcántara, A.; Fernandez-Lafuente, R. Enzyme-coated micro-crystals: An almost forgotten but very simple and elegant immobilization strategy. Catalysts 2020, 10, 891. [CrossRef]

55. Rueda, N.; dos Santos, J.; Torres, R.; Ortiz, C.; Barbosa, O.; Fernandez-Lafuente, R. Immobilization of lipases on heterofunctional octyl-glyoxyl agarose supports. Meth. Enzymol. 2016, 571, 73-85. [CrossRef]

56. Monteiro, R.R.C.; Neto, D.M.A.; Fechine, P.B.A.; Lopes, A.A.S.; Gonçalves, L.R.B.; Dos Santos, J.C.S.; De Souza, M.C.M.; Fernandez-Lafuente, R. Ethyl butyrate synthesis catalyzed by lipases A and B from candida antarctica immobilized onto magnetic nanoparticles. improvement of biocatalysts' performance under ultrasonic irradiation. Int. J. Mol. Sci. 2019, 20, 5807. [CrossRef] [PubMed]

57. Rios, N.S.; Morais, E.G.; Galvão, W.D.S.; Neto, D.M.A.; dos Santos, J.C.S.; Bohn, F.; Correa, M.A.; Fechine, P.B.A.; FernandezLafuente, R.; Gonçalves, L.R.B. Further stabilization of lipase from Pseudomonas fluorescens immobilized on octyl coated nanoparticles via chemical modification with bifunctional agents. Int. J. Biol. Macromol. 2019, 141, 313-324. [CrossRef] [PubMed]

58. Virgen-Ortíz, J.J.; dos Santos, J.C.; Ortiz, C.; Berenguer-Murcia, A.; Barbosa, O.; Rodrigues, R.; Fernandez-Lafuente, R. Lecitase ultra: A phospholipase with great potential in biocatalysis. Mol. Catal. 2019, 473, 110405. [CrossRef]

59. Rueda, N.; dos Santos, J.C.S.; Torres, R.; Barbosa, O.; Ortiz, C.; Fernandez-Lafuente, R. Reactivation of lipases by the unfolding and refolding of covalently immobilized biocatalysts. RSC Adv. 2015, 5, 55588-55594. [CrossRef]

60. Tom, R.J.; Sankaranarayanan, S.; Rodrigues, J.J.P.C. Smart energy management and demand reduction by consumers and utilities in an IoT-fog-based power distribution system. IEEE Internet Things J. 2019, 6, 7386-7394. [CrossRef]

61. Wancura, J.H.C.; Rosset, D.V.; Tres, M.V.; Oliveira, J.V.; Mazutti, M.A.; Jahn, S.L. Production of biodiesel catalyzed by lipase from Thermomyces lanuginosus in its soluble form. Can. J. Chem. Eng. 2018, 96, 2361-2368. [CrossRef]

62. Rueda, N.; dos Santos, J.C.S.; Rodriguez, M.D.; Albuquerque, T.L.; Barbosa, O.; Torres, R.T.R.; Ortiz, C.; Fernandez-Lafuente, R. Reversible immobilization of lipases on octyl-glutamic agarose beads: A mixed adsorption that reinforces enzyme immobilization. J. Mol. Catal. B Enzym. 2016, 128, 10-18. [CrossRef]

63. Rueda, N.; Albuquerque, T.L.; Bartolome-Cabrero, R.; Fernandez-Lopez, L.; Torres, R.; Ortiz, C.; Dos Santos, J.C.S.; Barbosa, O.; Fernandez-Lafuente, R. Reversible immobilization of lipases on heterofunctional octyl-amino agarose beads prevents enzyme desorption. Molecules 2016, 21, 646. [CrossRef]

64. Rios, N.S.; Neto, D.M.A.; dos Santos, J.C.S.; Fechine, P.B.A.; Fernández-Lafuente, R.; Gonçalves, L.R.B. Comparison of the immobilization of lipase from Pseudomonas fluorescens on divinylsulfone or p-benzoquinone activated support. Int. J. Biol. Macromol. 2019, 134, 936-945. [CrossRef] 
65. De Souza, T.C.; Fonseca, T.D.S.; da Costa, J.A.; Rocha, M.V.P.; de Mattos, M.C.; Fernandez-Lafuente, R.; Gonçalves, L.R.; dos Santos, J.C.S. Cashew apple bagasse as a support for the immobilization of lipase B from Candida antarctica: Application to the chemoenzymatic production of (R)-Indanol. J. Mol. Catal. B Enzym. 2016, 130, 58-69. [CrossRef]

66. Fernandez-Lopez, L.; Rueda, N.; Bartolome-Cabrero, R.; Rodriguez, M.D.; Albuquerque, T.L.; dos Santos, J.C.; Barbosa, O.; Fernandez-Lafuente, R. Improved immobilization and stabilization of lipase from Rhizomucor miehei on octyl-glyoxyl agarose beads by using $\mathrm{CaCl}$. Process. Biochem. 2016, 51, 48-52. [CrossRef]

67. Dos Santos, J.C.S.; Rueda, N.; Goncalves, L.R.B.; Fernandez-Lafuente, R. Tuning the catalytic properties of lipases immobilized on divinylsulfone activated agarose by altering its nanoenvironment. Enzym. Microb. Technol. 2015, 77, 1-7. [CrossRef] [PubMed]

68. Rueda, N.; dos Santos, J.C.S.; Ortiz, C.; Barbosa, O.; Fernandez-Lafuente, R.; Torres, R.T.R. Chemical amination of lipases improves their immobilization on octyl-glyoxyl agarose beads. Catal. Today 2016, 259, 107-118. [CrossRef]

69. Thangaraj, B.; Solomon, P.R. Immobilization of lipases-A Review. Part I: Enzyme immobilization. ChemBioEng Rev. 2019, 6, 157-166. [CrossRef]

70. Moreira, K.D.S.; De Oliveira, A.L.B.; Júnior, L.S.D.M.; Monteiro, R.R.C.; Da Rocha, T.N.; de Menezes, F.L.; Fechine, L.; DeNardin, J.C.; Michea, S.; Freire, R.M.; et al. Lipase from rhizomucor miehei immobilized on magnetic nanoparticles: Performance in Fatty Acid Ethyl Ester (FAEE) optimized production by the taguchi method. Front. Bioeng. Biotechnol. 2020, 8, 693. [CrossRef]

71. Monteiro, R.R.C.; Lima, P.J.M.; Pinheiro, B.; Freire, T.M.; Dutra, L.M.U.; Fechine, L.; Gonçalves, L.R.B.; De Souza, M.C.M.; Dos Santos, J.C.S.; Fernandez-Lafuente, R. Immobilization of lipase A from candida antarctica onto chitosan-coated magnetic nanoparticles. Int. J. Mol. Sci. 2019, 20, 4018. [CrossRef]

72. Fernandez-Lopez, L.; Bartolome-Cabrero, R.; Rodriguez, M.D.; Dos Santos, C.S.; Rueda, N.; Fernandez-Lafuente, R. Stabilizing effects of cations on lipases depend on the immobilization protocol. RSC Adv. 2015, 5, 83868-83875. [CrossRef]

73. Mateo, C.; Palomo, J.M.; Lorente, F.; Guisan, J.M.; Fernandez-Lafuente, R. Improvement of enzyme activity, stability and selectivity via immobilization techniques. Enzym. Microb. Technol. 2007, 40, 1451-1463. [CrossRef]

74. Sheldon, R.A.; Woodley, J. Role of biocatalysis in sustainable chemistry. Chem. Rev. 2017, 118, 801-838. [CrossRef] [PubMed]

75. Chapman, J.; Ismail, A.E.; Dinu, C.Z. Industrial applications of enzymes: Recent advances, techniques, and outlooks. Catalysts 2018, 8, 238. [CrossRef]

76. Madhavan, A.; Sindhu, R.; Binod, P.; Sukumaran, R.K.; Pandey, A. Strategies for design of improved biocatalysts for industrial applications. Bioresour. Technol. 2017, 245, 1304-1313. [CrossRef]

77. Bilal, M.; Asgher, M.; Parra, R.; Hu, H.; Wang, W.; Zhang, X.; Iqbal, H.M. Immobilized ligninolytic enzymes: An innovative and environmental responsive technology to tackle dye-based industrial pollutants-A review. Sci. Total Environ. 2016, 576, 646-659. [CrossRef]

78. Liu, D.-M.; Chen, J.; Shi, Y.-P. Advances on methods and easy separated support materials for enzymes immobilization. TrAC Trends Anal. Chem. 2018, 102, 332-342. [CrossRef]

79. Bilal, M.; Iqbal, H.M. Naturally-derived biopolymers: Potential platforms for enzyme immobilization. Int. J. Biol. Macromol. 2019, 130, 462-482. [CrossRef] [PubMed]

80. Drout, R.J.; Robison, L.; Farha, O.K. Catalytic applications of enzymes encapsulated in metal-organic frameworks. Coord. Chem. Rev. 2018, 381, 151-160. [CrossRef]

81. Ismail, A.R.; Baek, K.-H. Lipase immobilization with support materials, preparation techniques, and applications: Present and future aspects. Int. J. Biol. Macromol. 2020, 163, 1624-1639. [CrossRef] [PubMed]

82. Karav, S.; Cohen, J.L.; Barile, D.; Bell, J.M.L.N. Recent advances in immobilization strategies for glycosidases. Biotechnol. Prog. 2016, 33, 104-112. [CrossRef] [PubMed]

83. Nguyen, H.H.; Kim, A.M. An overview of techniques in enzyme immobilization. Appl. Sci. Converg. Technol. 2017, 26, 157-163. [CrossRef]

84. De Oliveira, U.M.F.; de Matos, L.J.B.L.; de Souza, M.C.M.; Pinheiro, B.B.; dos Santos, J.C.S.; Gonçalves, L.R.B. Efficient biotechnological synthesis of flavor esters using a low-cost biocatalyst with immobilized Rhizomucor miehei lipase. Mol. Biol. Rep. 2018, 46, 597-608. [CrossRef]

85. Dos Santos, J.C.S.; Garcia-Galan, C.; Rodrigues, R.; de Sant'Ana, H.B.; Goncalves, L.R.B.; Fernandez-Lafuente, R. Stabilizing hyperactivated lecitase structures through physical treatment with ionic polymers. Process. Biochem. 2014, 49, 1511-1515. [CrossRef]

86. Verdasco-Martín, C.M.; Villalba, M.; dos Santos, J.C.; Tobajas, M.; Fernandez-Lafuente, R.; Otero, C. Effect of chemical modification of Novozym 435 on its performance in the alcoholysis of camelina oil. Biochem. Eng. J. 2016, 111, 75-86. [CrossRef]

87. Garcia-Galan, C.; Barbosa, O.; Hernandez, K.; Dos Santos, J.C.S.; Rodrigues, R.C.; Fernandez-Lafuente, R. Evaluation of styrene-divinylbenzene beads as a support to immobilize lipases. Molecules 2014, 19, 7629-7645. [CrossRef]

88. Chi, M.-C.; Huang, Y.-F.; Lu, B.-Y.; Lin, M.-G.; Wang, T.-F.; Lin, L.-L. Magnetic cross-linked enzyme aggregates of a transpeptidasespecialized variant (N450D) of Bacillus licheniformis $\gamma$-Glutamyl transpeptidase: An efficient and stable biocatalyst for L-theanine synthesis. Catalysts 2021, 11, 243. [CrossRef]

89. Sheldon, R.A. Cross-linked enzyme aggregates as industrial biocatalysts. Org. Process. Res. Dev. 2011, 15, 213-223. [CrossRef]

90. Rehman, S.; Bhatti, H.N.; Bilal, M.; Asgher, M. Cross-linked enzyme aggregates (CLEAs) of Pencilluim notatum lipase enzyme with improved activity, stability and reusability characteristics. Int. J. Biol. Macromol. 2016, 91, 1161-1169. [CrossRef] [PubMed] 
91. Chen, Z.; Wang, Y.; Liu, W.; Wang, J.; Chen, H. A novel cross-linked enzyme aggregates (CLEAs) of papain and neutraseproduction, partial characterization and application. Int. J. Biol. Macromol. 2017, 95, 650-657. [CrossRef]

92. Jin, W.; Xu, Y.; Yu, X.-W. Formation lipase cross-linked enzyme aggregates on octyl-modified mesocellular foams with oxidized sodium alginate. Colloids Surf. B Biointerfaces 2019, 184, 110501. [CrossRef]

93. Ramos, M.D.; Miranda, L.P.; Fernandez-Lafuente, R.; Kopp, W.; Tardioli, P.W. Improving the yields and reaction rate in the ethanolysis of soybean oil by using mixtures of lipase CLEAs. Molecules 2019, 24, 4392. [CrossRef]

94. Yan, L.; Ma, P.; Liu, Y.; Xiaoyan, M.; Chen, F.; Li, M. 3D coral-like gold/carbon paper electrode modified with covalent and cross-linked enzyme aggregates for electrochemical sensing of glucose. Microchem. J. 2020, 159, 105347. [CrossRef]

95. De Sousa, M.; Gurgel, B.S.; Pessela, B.C.; Gonçalves, L.R. Preparation of CLEAs and magnetic CLEAs of a recombinant l-arabinose isomerase for d-tagatose synthesis. Enzym. Microb. Technol. 2020, 138, 109566. [CrossRef] [PubMed]

96. Li, S.; Su, Y.; Liu, Y.; Sun, L.; Yu, M.; Wu, Y. Preparation and characterization of cross-linked enzyme aggregates (CLEAs) of recombinant thermostable alkylsulfatase (SdsAP) from Pseudomonas sp. Process. Biochem. 2016, 51, 2084-2089. [CrossRef]

97. Hong, J.; Jung, D.; Park, S.; Oh, Y.; Oh, K.K.; Lee, S.H. Immobilization of laccase via cross-linked enzyme aggregates prepared using genipin as a natural cross-linker. Int. J. Biol. Macromol. 2021, 169, 541-550. [CrossRef]

98. Mehde, A.A.; Mehdi, W.A.; Özacar, M.; Özacar, Z.Z. Evaluation of different saccharides and chitin as eco-friendly additive to improve the magnetic cross-linked enzyme aggregates (CLEAs) activities. Int. J. Biol. Macromol. 2018, 118, 2040-2050. [CrossRef] [PubMed]

99. Wahab, M.K.H.A.; El-Enshasy, H.A.; Abu Bakar, F.D.; Murad, A.M.A.; Jahim, J.M.; Illias, R.M. Improvement of cross-linking and stability on cross-linked enzyme aggregate (CLEA)-xylanase by protein surface engineering. Process. Biochem. 2019, 86, 40-49. [CrossRef]

100. Schoevaart, R.; Wolbers, M.; Golubovic, M.; Ottens, M.; Kieboom, A.; van Rantwijk, F.; van der Wielen, L.; Sheldon, R. Preparation, optimization, and structures of cross-linked enzyme aggregates (CLEAs). Biotechnol. Bioeng. 2004, 87, 754-762. [CrossRef] [PubMed]

101. Doraiswamy, N.; Sarathi, M.; Pennathur, G. Cross-linked esterase aggregates (CLEAs) using nanoparticles as immobilization matrix. Prep. Biochem. Biotechnol. 2019, 49, 270-278. [CrossRef]

102. Matijošyte, I.; Arends, I.; de Vries, S.; Sheldon, R.A. Preparation and use of cross-linked enzyme aggregates (CLEAs) of laccases. J. Mol. Catal. B Enzym. 2010, 62, 142-148. [CrossRef]

103. Guajardo, N.; Ahumada, K.; de María, P.D. Immobilization of pseudomonas stutzeri lipase through cross-linking aggregates (CLEA) for reactions in deep eutectic solvents. J. Biotechnol. 2021, 337, 18-23. [CrossRef] [PubMed]

104. Nadar, S.; Rathod, V.K. Magnetic macromolecular cross linked enzyme aggregates (CLEAs) of glucoamylase. Enzym. Microb. Technol. 2016, 83, 78-87. [CrossRef]

105. Carneiro, E.; Bastos, A.; De Oliveira, U.; De Matos, L.; Adriano, W.; Monteiro, R.; Dos Santos, J.; Gonçalves, L. improving the catalytic features of the lipase from rhizomucor miehei immobilized on chitosan-based hybrid matrices by altering the chemical activation conditions. Quimica Nova 2020,43, 1234-1239. [CrossRef]

106. Reis, C.; Sousa, E.; Serpa, J.; Oliveira, R.; Santos, J. Design of immobilized enzyme biocatalysts: Drawbacks and opportunities. Química Nova 2019, 42, 768-783. [CrossRef]

107. Barbosa, O.; Ortiz, C.; Berenguer-Murcia, A.; Torres, R.; Rodrigues, R.C.; Fernandez-Lafuente, R. Glutaraldehyde in bio-catalysts design: A useful crosslinker and a versatile tool in enzyme immobilization. RSC Adv. 2013, 4, 1583-1600. [CrossRef]

108. Betancor, L.; López-Gallego, F.; Alonso-Morales, N.; Dellamora, G.; Mateo, C.; Fernandez-Lafuente, R.; Guisán, J.M. Glutaraldehyde in protein immobilization. Phytoremediation 2006, 22, 57-64. [CrossRef]

109. De Oliveira, A.L.B.; Cavalcante, F.T.T.; Moreira, K.S.; Monteiro, R.R.C.; Rocha, T.G.; Souza, J.E.S.; da Fonseca, A.M.; Lopes, A.A.S.; Guimarães, A.P.; de Lima, R.K.C.; et al. Lipases immobilized onto nanomaterials as biocatalysts in biodiesel production: Scientific context, challenges, and opportunities. Rev. Virtual Quim. 2021, 13, 875-891. [CrossRef]

110. Nunes, Y.L.; de Menezes, F.L.; de Sousa, I.G.; Cavalcante, A.L.G.; Cavalcante, F.T.T.; Moreira, K.d.S.; de Oliveira, A.L.B.; Mota, G.F.; Souza, J.E.D.S.; Falcão, I.R.D.A.; et al. Chemical and physical chitosan modification for designing enzymatic industrial biocatalysts: How to choose the best strategy? Int. J. Biol. Macromol. 2021, 181, 1124-1170. [CrossRef]

111. Bezerra, R.M.; Neto, D.M.A.; Galvão, W.; Rios, N.; Carvalho, A.C.L.D.M.; Correa, M.; Bohn, F.; Fernandez-Lafuente, R.; Fechine, P.; de Mattos, M.C.; et al. Design of a lipase-nano particle biocatalysts and its use in the kinetic resolution of medicament precursors. Biochem. Eng. J. 2017, 125, 104-115. [CrossRef]

112. Betancor, L.; Gallego, F.L.; Hidalgo, A.; Alonso-Morales, N.; Mateo, G.D.-O.C.; Fernández-Lafuente, R.; Guisán, J.M. Different mechanisms of protein immobilization on glutaraldehyde activated supports: Effect of support activation and immobilization conditions. Enzym. Microb. Technol. 2006, 39, 877-882. [CrossRef]

113. Liao, Q.; Du, X.; Jiang, W.; Tong, Y.; Zhao, Z.; Fang, R.; Feng, J.; Tang, L. Cross-linked enzyme aggregates (CLEAs) of halohydrin dehalogenase from Agrobacterium radiobacter AD1: Preparation, characterization and application as a biocatalyst. J. Biotechnol. 2018, 272-273, 48-55. [CrossRef]

114. Wang, S.; Zheng, D.; Yin, L.; Wang, F. Preparation, activity and structure of cross-linked enzyme aggregates (CLEAs) with nanoparticle. Enzym. Microb. Technol. 2017, 107, 22-31. [CrossRef] [PubMed] 
115. Grajales-Hernández, D.; Armendáriz-Ruiz, M.; Velasco-Lozano, S.; López-Gallego, F.; Mateos-Díaz, J.C. Chitosan-based CLEAs from Aspergillus niger type A feruloyl esterase: High-productivity biocatalyst for alkyl ferulate synthesis. Appl. Microbiol. Biotechnol. 2020, 104, 10033-10045. [CrossRef] [PubMed]

116. Tikhonov, B.B.; Sulman, E.M.; Stadol'Nikova, P.Y.; Golikova, E.P.; Sidorov, A.I.; Matveeva, V.G. Immobilized enzymes from the class of oxidoreductases in technological processes: A review. Catal. Ind. 2019, 11, 251-263. [CrossRef]

117. Cui, J.; Zhao, Y.; Tan, Z.; Zhong, C.; Han, P.; Jia, S. Mesoporous phenylalanine ammonia lyase microspheres with improved stability through calcium carbonate templating. Int. J. Biol. Macromol. 2017, 98, 887-896. [CrossRef]

118. Kumar, A.; Wu, G.; Liu, Z. Synthesis and characterization of cross linked enzyme aggregates of serine hydroxyl methyltransferase from Idiomerina leihiensis. Int. J. Biol. Macromol. 2018, 117, 683-690. [CrossRef]

119. Araya, E.; Urrutia, P.; Romero, O.; Illanes, A.; Wilson, L. Design of combined crosslinked enzyme aggregates (combi-CLEAs) of $\beta$-galactosidase and glucose isomerase for the one-pot production of fructose syrup from lactose. Food Chem. 2019, 288, 102-107. [CrossRef]

120. Sheldon, R.A. CLEAs, Combi-CLEAs and 'Smart' magnetic CLEAs: Biocatalysis in a bio-based economy. Catalysts 2019, 9, 261. [CrossRef]

121. Da Fonseca, A.M.; Dos Santos, J.C.S.; De Souza, M.C.M.; de Oliveira, M.M.; Colares, R.P.; De Lemos, T.L.G.; Filho, R.B. The use of new hydrogel microcapsules in coconut juice as biocatalyst system for the reaction of quinine. Ind. Crop. Prod. 2019, 145, 111890. [CrossRef]

122. Muley, A.B.; Awasthi, S.; Bhalerao, P.P.; Jadhav, N.L.; Singhal, R.S. Preparation of cross-linked enzyme aggregates of lipase from Aspergillus niger: Process optimization, characterization, stability, and application for epoxidation of lemongrass oil. Bioprocess Biosyst. Eng. 2021, 44, 1383-1404. [CrossRef]

123. Ahmed, I.; Jhung, S.H. Covalent organic framework-based materials: Synthesis, modification, and application in environmental remediation. Coord. Chem. Rev. 2021, 441, 213989. [CrossRef]

124. Ning, J.; Gao, Y.; Cao, X.; Wei, H.; Wang, B.; Hao, L. Substituent engineering of covalent organic frameworks modulates the crystallinity and electrochemical reactivity. J. Energy Chem. 2021, 65, 490-496. [CrossRef]

125. Xin, J.; Wang, X.; Li, N.; Liu, L.; Lian, Y.; Wang, M.; Zhao, R.-S. Recent applications of covalent organic frameworks and their multifunctional composites for food contaminant analysis. Food Chem. 2020, 330, 127255. [CrossRef] [PubMed]

126. Gonçalves, R.S.B.; de Oliveira, A.B.V.; Sindra, H.C.; Archanjo, B.S.; Mendoza, M.E.; Carneiro, L.S.A.; Buarque, C.D.; Esteves, P.M. Heterogeneous catalysis by covalent organic frameworks (COF): $\mathrm{Pd}(\mathrm{OAc})$ 2@COF-300 in cross-coupling reactions. ChemCatChem 2016, 8, 743-750. [CrossRef]

127. Abuzeid, H.R.; El-Mahdy, A.F.; Kuo, S.-W. Covalent organic frameworks: Design principles, synthetic strategies, and diverse applications. Giant 2021, 6, 100054. [CrossRef]

128. Gendy, E.A.; Ifthikar, J.; Ali, J.; Oyekunle, D.T.; Elkhlifia, Z.; Shahib, I.I.; Khodair, A.I.; Chen, Z. Removal of heavy metals by covalent organic frameworks (COFs): A review on its mechanism and adsorption properties. J. Environ. Chem. Eng. 2021, 9, 105687. [CrossRef]

129. Wang, H.; Wanga, T.; Maa, R.; Wua, K.; Lia, H.; Fengb, B.; Lib, C.; Shenb, Y. Facile synthesis of sulfonated covalent organic framework for the adsorption of heavy metal ions. J. Taiwan Inst. Chem. Eng. 2020, 112, 122-129. [CrossRef]

130. Bao, T.; Wang, S.; Zhang, N.; Zhang, J. Facile synthesis and immobilization of functionalized covalent organic framework-1 for electrochromatographic separation. J. Chromatogr. A 2021, 1645, 462130. [CrossRef]

131. Gong, K.; Zhang, D.; Wang, Y.; Li, C.; Zhang, H.; Li, H.; Feng, H. Biguanide-functionalized hierarchical porous covalent organic frameworks for efficient catalysis of condensation reactions. Mol. Catal. 2021, 509, 111663. [CrossRef]

132. Khan, N.A.; Wu, H.; Jinqiu, Y.; Mengyuan, W.; Yang, P.; Long, M.; Rahman, A.U.; Ahmad, N.M.; Zhang, R.; Jiang, Z. Incorporating covalent organic framework nanosheets into polyamide membranes for efficient desalination. Sep. Purif. Technol. 2021, 274, 119046. [CrossRef]

133. Segura, J.L.; Mancheño, M.J.; Zamora, F. Covalent organic frameworks based on Schiff-base chemistry: Synthesis, properties and potential applications. Chem. Soc. Rev. 2016, 45, 5635-5671. [CrossRef] [PubMed]

134. Bagheri, A.R.; Aramesh, N.; Sher, F.; Bilal, M. Covalent organic frameworks as robust materials for mitigation of environmental pollutants. Chemosphere 2021, 270, 129523. [CrossRef] [PubMed]

135. He, J.; Luo, B.; Zhang, H.; Li, Z.; Zhu, N.; Lan, F.; Wu, Y. Surfactant-free synthesis of covalent organic framework nanospheres in water at room temperature. J. Colloid Interface Sci. 2021, 606, 1333-1339. [CrossRef]

136. Yang, Q.; Luo, M.; Liu, K.; Cao, H.; Yan, H. Covalent organic frameworks for photocatalytic applications. Appl. Catal. B Environ. 2020, 276, 119174. [CrossRef]

137. Feng, X.; Ding, X.; Jiang, D. Covalent organic frameworks. Chem. Soc. Rev. 2012, 41, 6010-6022. [CrossRef] [PubMed]

138. Pan, F.; Tong, C.; Wang, Z.; Xu, F.; Wang, X.; Weng, B.; Pan, D.; Zhu, R. Novel sulfhydryl functionalized covalent organic frameworks for ultra-trace $\mathrm{Hg} 2+$ removal from aqueous solution. J. Mater. Sci. Technol. 2021, 93, 89-95. [CrossRef]

139. Huang, M.; Chong, J.; Hu, C.; Yang, Y. Ratiometric fluorescent detection of temperature and MnO4-Using a modified covalent organic framework. Inorg. Chem. Commun. 2020, 119, 108094. [CrossRef]

140. Xu, S.; Zhang, Q. Recent progress in covalent organic frameworks as light-emitting materials. Mater. Today Energy 2021, $20,100635$. [CrossRef] 
141. Gan, J.; Bagheri, A.R.; Aramesh, N.; Gul, I.; Franco, M.; Almulaiky, Y.Q.; Bilal, M. Covalent organic frameworks as emerging host platforms for enzyme immobilization and robust biocatalysis-A review. Int. J. Biol. Macromol. 2020, 167, 502-515. [CrossRef]

142. Sun, Q.; Fu, C.-W.; Aguila, B.; Perman, J.A.; Wang, S.; Huang, H.-Y.; Xiao, F.-S.; Ma, S. Pore environment control and enhanced performance of enzymes infiltrated in covalent organic frameworks. J. Am. Chem. Soc. 2018, 140, 984-992. [CrossRef]

143. Oliveira, F.L.; França, A.D.S.; De Castro, A.M.; Souza, R.O.M.A.; Esteves, P.M.; Goncalves, R.S.B. Enzyme immobilization in covalent organic frameworks: Strategies and applications in biocatalysis. Chem. Plus Chem. 2020, 85. [CrossRef] [PubMed]

144. Yusran, Y.; Li, H.; Guan, X.; Fang, Q.; Qiu, S. Covalent Organic Frameworks for Catalysis. Energy Chem. 2020, 2, 100035. [CrossRef]

145. Sun, Q.; Aguila, B.; Lan, P.C.; Ma, S. Tuning pore heterogeneity in covalent organic frameworks for enhanced enzyme accessibility and resistance against denaturants. Adv. Mater. 2019, 31, e1900008. [CrossRef] [PubMed]

146. Oliveira, F.L.; De Souza, S.P.; Bassut, J.; Álvarez, H.M.; Garcia-Basabe, Y.; De Souza, R.O.M.A.; Esteves, P.M.; Goncalves, R.S.B. Enzyme-decorated covalent organic frameworks as nanoporous platforms for heterogeneous biocatalysis. Chem. A Eur. J. 2019, 25, 15863-15870. [CrossRef] [PubMed]

147. Zhou, Z.-W.; Cai, C.-X.; Xing, X.; Li, J.; Hu, Z.-E.; Xie, Z.-B.; Wang, N.; Yu, X.-Q. Magnetic COFs as satisfied support for lipase immobilization and recovery to effectively achieve the production of biodiesel by great maintenance of enzyme activity. Biotechnol. Biofuels 2021, 14, 1-12. [CrossRef]

148. El-Kaderi, H.M.; Hunt, J.R.; Mendoza-Cortés, J.L.; Côté, A.P.; Taylor, R.E.; O’Keeffe, M.; Yaghi, O.M. Designed synthesis of 3D covalent organic frameworks. Science 2007, 316, 268-272. [CrossRef]

149. Sharma, R.K.; Yadav, P.; Yadav, M.; Gupta, R.; Rana, P.; Srivastava, A.; Zbořil, R.; Varma, R.S.; Antonietti, M.; Gawande, M.B. Recent development of covalent organic frameworks (COFs): Synthesis and catalytic (organic-electro-photo) applications. Mater. Horizons 2019, 7, 411-454. [CrossRef]

150. Wang, Z.; Zhang, S.; Chen, Y.; Zhang, Z.; Ma, S. Covalent organic frameworks for separation applications. Chem. Soc. Rev. 2020, 49, 708-735. [CrossRef]

151. Nguyen, H.L.; Gropp, C.; Yaghi, O.M. Reticulating 1D ribbons into 2D covalent organic frameworks by imine and imide linkages. J. Am. Chem. Soc. 2020, 142, 2771-2776. [CrossRef]

152. Wen, A.; Li, G.; Wu, D.; Yu, Y.; Yang, Y.; Hu, N.; Wang, H.; Chen, J.; Wu, Y. Sulphonate functionalized covalent organic framework-based magnetic sorbent for effective solid phase extraction and determination of fluoroquinolones. J. Chromatogr. A 2019, 1612, 460651. [CrossRef]

153. Su, D.; Feng, B.; Xu, P.; Zeng, Q.; Shan, B.; Song, Y. Covalent organic frameworks and electron mediator-based open circuit potential biosensor for in vivo electrochemical measurements. Anal. Methods 2018, 10, 4320-4328. [CrossRef]

154. Samui, A.; Happy; Sahu, S.K. Integration of $\alpha$-amylase into covalent organic framework for highly efficient biocatalyst. Microporous Mesoporous Mater. 2020, 291. [CrossRef]

155. Zhao, M.; Zhang, X.; Deng, C. Rational synthesis of novel recyclable Fe3O4@MOF nanocomposites for enzymatic digestion. Chem. Commun. 2015, 51, 8116-8119. [CrossRef] [PubMed]

156. Wiśniewski, J.R.; Mann, M. Consecutive proteolytic digestion in an enzyme reactor increases depth of proteomic and phosphoproteomic analysis. Anal. Chem. 2012, 84, 2631-2637. [CrossRef]

157. Wang, L.; Liang, H.; Xu, M.; Wang, L.; Xie, Y.; Song, Y. Ratiometric electrochemical biosensing based on double-enzymes loaded on two-dimensional dual-pore COFETTA-TPAL. Sens. Actuators B Chem. 2019, 298. [CrossRef]

158. Zhang, G.; Jin, L.; Zhang, R.; Bai, Y.; Zhu, R.; Pang, H. Recent advances in the development of electronically and ionically conductive metal-organic frameworks. Coord. Chem. Rev. 2021, 439, 213915. [CrossRef]

159. Whelan, É.; Steuber, F.W.; Gunnlaugsson, T.; Schmitt, W. Tuning photoactive metal-organic frameworks for luminescence and photocatalytic applications. Coord. Chem. Rev. 2021, 437, 213757. [CrossRef]

160. Wang, S.; McGuirk, C.M.; D'Aquino, A.; Mason, J.A.; Mirkin, C.A. Metal-Organic framework nanoparticles. Adv. Mater. 2018, 30, e1800202. [CrossRef]

161. Chen, L.; Xu, Q. Metal-Organic Framework Composites for Catalysis. Matter 2019, 1, 57-89. [CrossRef]

162. Chuhadiya, S.; Himanshu; Suthar, D.; Patel, S.; Dhaka, M. Metal organic frameworks as hybrid porous materials for energy storage and conversion devices: A review. Coord. Chem. Rev. 2021, 446, 214115. [CrossRef]

163. Li, R.; Zhang, W.; Zhou, K. Metal-Organic-framework-based catalysts for photoreduction of CO. Adv. Mater. 2018, 30 , e1705512. [CrossRef]

164. Li, D.-Z.; Chen, L.; Liu, G.; Yuan, Z.-Y.; Li, B.-F.; Zhang, X.; Wei, J.-Q. Porous metal-organic frameworks for methane storage and capture: Status and challenges. New Carbon Mater. 2021, 36, 468-496. [CrossRef]

165. Zhu, Q.-L.; Xu, Q. Metal-organic framework composites. Chem. Soc. Rev. 2014, 43, 5468-5512. [CrossRef]

166. Chen, Y.-Z.; Zhang, R.; Jiao, L.; Jiang, H.-L. Metal-organic framework-derived porous materials for catalysis. Coord. Chem. Rev. 2018, 362, 1-23. [CrossRef]

167. Dutta, A.; Pan, Y.; Liu, J.-Q.; Kumar, A. Multicomponent isoreticular metal-organic frameworks: Principles, current status and challenges. Coord. Chem. Rev. 2021, 445, 214074. [CrossRef]

168. Dybtsev, D.N.; Bryliakov, K.P. Asymmetric catalysis using metal-organic frameworks. Coord. Chem. Rev. 2021, 437, 213845. [CrossRef] 
169. Guo, W.; Cheng, J.; Song, Y.; Liu, S.; Ali, K.A.; Kumar, S. Three-dimensional numerical simulation of light penetration in an optimized flow field composed of microalgae cells, carbon dioxide bubbles and culture medium. Bioresour. Technol. 2019, 292, 121979. [CrossRef] [PubMed]

170. Kong, X.-J.; Li, J.-R. An Overview of Metal-Organic frameworks for green chemical engineering. Engineering 2021, 7, 1115-1139. [CrossRef]

171. Qi, L.; Luo, Z.; Lu, X. Biomimetic mineralization inducing lipase-metal-organic framework nanocomposite for pickering interfacial biocatalytic system. ACS Sustain. Chem. Eng. 2019, 7, 7127-7139. [CrossRef]

172. Qin, Y.; Wan, Y.; Guo, J.; Zhao, M. Two-dimensional metal-organic framework nanosheet composites: Preparations and applications. Chin. Chem. Lett. 2021. [CrossRef]

173. Nemiwal, M.; Gosu, V.; Zhang, T.C.; Kumar, D. Metal organic frameworks as electrocatalysts: Hydrogen evolution reactions and overall water splitting. Int. J. Hydrogen Energy 2021, 46, 10216-10238. [CrossRef]

174. Konnerth, H.; Matsagar, B.M.; Chen, S.S.; Prechtl, M.H.; Shieh, F.-K.; Wu, K.C.-W. Metal-organic framework (MOF)-derived catalysts for fine chemical production. Coord. Chem. Rev. 2020, 416, 213319. [CrossRef]

175. Lin, C.; Xu, K.; Zheng, R.; Zheng, Y. Immobilization of amidase into a magnetic hierarchically porous metal-organic framework for efficient biocatalysis. Chem. Commun. 2019, 55, 5697-5700. [CrossRef]

176. Marsh, C.; Shearer, G.C.; Knight, B.T.; Paul-Taylor, J.; Burrows, A.D. Supramolecular aspects of biomolecule interactions in metal-organic frameworks. Coord. Chem. Rev. 2021, 439, 213928. [CrossRef]

177. Vahabi, A.H.; Norouzi, F.; Sheibani, E.; Rahimi-Nasrabadi, M. Functionalized Zr-UiO-67 metal-organic frameworks: Structural landscape and application. Coord. Chem. Rev. 2021, 445, 214050. [CrossRef]

178. He, J.; Sun, S.; Zhou, Z.; Yuan, Q.; Liu, Y.; Liang, H. Thermostable enzyme-immobilized magnetic responsive Ni-based metalorganic framework nanorods as recyclable biocatalysts for efficient biosynthesis of S-adenosylmethionine. Dalton Trans. 2019, 48, 2077-2085. [CrossRef]

179. Jiao, L.; Jiang, H.-L. Metal-organic-framework-based single-atom catalysts for energy applications. Chem 2019, 5, 786-804. [CrossRef]

180. Feng, Y.; Hu, H.; Wang, Z.; Du, Y.; Zhong, L.; Zhang, C.; Jiang, Y.; Jia, S.; Cui, J. Three-dimensional ordered magnetic macroporous metal-organic frameworks for enzyme immobilization. J. Colloid Interface Sci. 2021, 590, 436-445. [CrossRef]

181. Farmakes, J.; Schuster, I.; Overby, A.; Alhalhooly, L.; Lenertz, M.; Li, Q.; Ugrinov, A.; Choi, Y.; Pan, Y.; Yang, Z. Enzyme immobilization on graphite oxide (GO) surface via one-pot synthesis of GO/metal-organic framework composites for largesubstrate biocatalysis. ACS Appl. Mater. Interfaces 2020, 12, 23119-23126. [CrossRef] [PubMed]

182. Pei, X.; Wu, Y.; Wang, J.; Chen, Z.; Liu, W.; Su, W.; Liu, F. Biomimetic mineralization of nitrile hydratase into a mesoporous cobalt-based metal-organic framework for efficient biocatalysis. Nanoscale 2019, 12, 967-972. [CrossRef]

183. Song, J.; He, W.; Shen, H.; Zhou, Z.; Li, M.; Su, P.; Yang, Y. Construction of multiple enzyme metal-organic frameworks biocatalyst via DNA scaffold: A promising strategy for enzyme encapsulation. Chem. Eng. J. 2019, 363, 174-182. [CrossRef]

184. Cui, J.D.; Feng, Y.; Jia, S. Silica encapsulated catalase@metal-organic framework composite: A highly stable and recyclable biocatalyst. Chem. Eng. J. 2018, 351, 506-514. [CrossRef]

185. Li, Q.; Chen, Y.; Bai, S.; Shao, X.; Jiang, L.; Li, Q. Immobilized lipase in bio-based metal-organic frameworks constructed by biomimetic mineralization: A sustainable biocatalyst for biodiesel synthesis. Colloids Surfaces B Biointerfaces 2020, $188,110812$. [CrossRef]

186. Li, P.; Modica, J.A.; Howarth, A.J.; Vargas L., E.; Moghadam, P.Z.; Snurr, R.Q.; Mrksich, M.; Hupp, J.T.; Farha, O.K. Toward Design Rules for Enzyme Immobilization in Hierarchical Mesoporous Metal-Organic Frameworks. Chem 2016, 1, 154-169. [CrossRef]

187. Gkaniatsou, E.; Sicard, C.; Ricoux, R.; Benahmed, L.; Bourdreux, F.; Zhang, Q.; Serre, C.; Mahy, J.; Steunou, N. Enzyme encapsulation in mesoporous metal-Organic frameworks for selective biodegradation of harmful dye molecules. Angew. Chem. Int. Ed. 2018, 57, 16141-16146. [CrossRef]

188. Li, P.; Chen, Q.; Wang, T.C.; Vermeulen, N.A.; Mehdi, B.L.; Dohnalkova, A.; Browning, N.D.; Shen, D.; Anderson, R.; GómezGualdrón, D.A.; et al. Hierarchically engineered mesoporous metal-organic frameworks toward cell-free immobilized enzyme systems. Chem 2018, 4, 1022-1034. [CrossRef]

189. Mehta, J.; Bhardwaj, N.; Bhardwaj, S.K.; Kim, K.-H.; Deep, A. Recent advances in enzyme immobilization techniques: Metalorganic frameworks as novel substrates. Coord. Chem. Rev. 2016, 322, 30-40. [CrossRef]

190. Liu, X.; Qi, W.; Wang, Y.; Su, R.; He, Z. A facile strategy for enzyme immobilization with highly stable hierarchically porous metal-organic frameworks. Nanoscale 2017, 9, 17561-17570. [CrossRef]

191. Tranchemontagne, D.J.; Mendoza-Cortes, J.; O’Keeffe, M.; Yaghi, O. Secondary building units, nets and bonding in the chemistry of metal-organic frameworks. Chem. Soc. Rev. 2009, 38, 1257-1283. [CrossRef] [PubMed]

192. Chen, K.; Wu, C.-D. Designed fabrication of biomimetic metal-organic frameworks for catalytic applications. Coord. Chem. Rev. 2019, 378, 445-465. [CrossRef]

193. Li, N.; Qiao, D.; Zhao, S.; Lin, Q.; Zhang, B.; Xie, F. 3D printing to innovate biopolymer materials for demanding applications: A review. Mater. Today Chem. 2021, 20, 100459. [CrossRef]

194. Palmara, G.; Frascella, F.; Roppolo, I.; Chiappone, A.; Chiadò, A. Functional 3D printing: Approaches and bioapplications. Biosens. Bioelectron. 2020, 175, 112849. [CrossRef] [PubMed] 
195. Jayapiriya, U.S.; Goel, S. Surface modified 3D printed carbon bioelectrodes for glucose/O2 enzymatic biofuel cell: Comparison and optimization. Sustain. Energy Technol. Assessments 2020, 42, 100811. [CrossRef]

196. Jiang, P.; Ji, Z.; Wang, X.; Zhou, F. Surface functionalization-A new functional dimension added to 3D printing. J. Mater. Chem. C 2020, 8, 12380-12411. [CrossRef]

197. Sans, V. Emerging trends in flow chemistry enabled by 3D printing: Robust reactors, biocatalysis and electrochemistry. Curr. Opin. Green Sustain. Chem. 2020, 25, 100367. [CrossRef]

198. Belgrano, F.D.S.; Diegel, O.; Pereira, N.; Hatti-Kaul, R. Cell immobilization on 3D-printed matrices: A model study on propionic acid fermentation. Bioresour. Technol. 2018, 249, 777-782. [CrossRef]

199. Yoon, H.S.; Yang, K.; Kim, Y.M.; Nam, K.; Roh, Y.H. Cellulose nanocrystals as support nanomaterials for dual droplet-based freeform 3D printing. Carbohydr. Polym. 2021, 272, 118469. [CrossRef] [PubMed]

200. Kirchmajer, D.M.; Iii, R.G.; Panhuis, M.I.H. An overview of the suitability of hydrogel-forming polymers for extrusion-based 3D-printing. J. Mater. Chem. B 2015, 3, 4105-4117. [CrossRef]

201. Peng, M.; Mittmann, E.; Wenger, L.; Hubbuch, J.; Engqvist, M.K.M.; Niemeyer, C.M.; Rabe, K.S. 3D-Printed phenacrylate decarboxylase flow reactors for the chemoenzymatic synthesis of 4-hydroxystilbene. Chem. A Eur. J. 2019, 25, 15998-16001. [CrossRef]

202. Shen, X.; Yang, M.; Cui, C.; Cao, H. In situ immobilization of glucose oxidase and catalase in a hybrid interpenetrating polymer network by 3D bioprinting and its application. Colloids Surfaces A Physicochem. Eng. Asp. 2019, 568, 411-418. [CrossRef]

203. Ye, J.; Chu, T.; Chu, J.; Gao, B.; He, B. A Versatile Approach for Enzyme Immobilization Using Chemically Modified 3D-Printed Scaffolds. ACS Sustain. Chem. Eng. 2019, 7, 18048-18054. [CrossRef]

204. De Santis, P.; Meyer, L.-E.; Kara, S. The rise of continuous flow biocatalysis - fundamentals, very recent developments and future perspectives. React. Chem. Eng. 2020, 5, 2155-2184. [CrossRef]

205. Valotta, A.; Maier, M.C.; Soritz, S.; Pauritsch, M.; Koenig, M.; Brouczek, D.; Schwentenwein, M.; Gruber-Woelfler, H. 3D printed ceramics as solid supports for enzyme immobilization: An automated DoE approach for applications in continuous flow. J. Flow Chem. 2021, 1-15. [CrossRef]

206. Zhang, J.; Gao, B.; Lva, K.; Kumissaya, L.; Wub, B.; Chua, J.; Heab, B. Specific immobilization of lipase on functionalized 3D printing scaffolds via enhanced hydrophobic interaction for efficient resolution of racemic 1-indanol. Biochem. Biophys. Res. Commun. 2021, 546, 111-117. [CrossRef] [PubMed]

207. Dos Santos, L.K.; Botti, R.F.; Innocentini, M.D.D.M.; Marques, R.F.C.; Colombo, P.; de Paula, A.V.; Flumignan, D.L. 3D printed geopolymer: An efficient support for immobilization of Candida rugosa lipase. Chem. Eng. J. 2021, 414, 128843. [CrossRef]

208. Molinero-Fernández, A.; López, M.; Escarpa, A. Electrochemical microfluidic micromotors-based immunoassay for C-Reactive protein determination in preterm neonatal samples with sepsis suspicion. Anal. Chem. 2020, 92, 5048-5054. [CrossRef]

209. Lin, F.; Zhao, X.; Wang, J.; Yu, S.; Deng, Y.; Geng, L.; Li, H. A novel microfluidic chip electrophoresis strategy for simultaneous, label-free, multi-protein detection based on a graphene energy transfer biosensor. Analyst 2014, 139, 2890-2895. [CrossRef] [PubMed]

210. Kim, D.; Herr, A. Protein immobilization techniques for microfluidic assays. Biomicrofluidics 2013, 7, 041501. [CrossRef] [PubMed]

211. Maxwell, E.J.; Mazzeo, A.D.; Whitesides, G.M. Paper-based electroanalytical devices for accessible diagnostic testing. MRS Bull. 2013, 38, 309-314. [CrossRef]

212. Pereiro, I.; Tabnaoui, S.; Fermigier, M.; du Roure, O.; Descroix, S.; Viovy, J.-L.; Malaquin, L. Magnetic fluidized bed for solid phase extraction in microfluidic systems. Lab a Chip 2017, 17, 1603-1615. [CrossRef] [PubMed]

213. Pereiro, I.; Bendali, A.; Tabnaoui, S.; Alexandre, L.; Srbova, J.; Bilkova, Z.; Deegan, S.; Joshi, L.; Viovy, J.-L.; Malaquin, L.; et al. A new microfluidic approach for the one-step capture, amplification and label-free quantification of bacteria from raw samples. Chem. Sci. 2016, 8, 1329-1336. [CrossRef]

214. Sasso, L.A.; Johnston, I.H.; Zheng, M.; Gupte, R.K.; Undar, A.; Zahn, J.D. Automated microfluidic processing platform for multiplexed magnetic bead immunoassays. Microfluid. Nanofluidics 2012, 13, 603-612. [CrossRef] [PubMed]

215. Cavalcante, F.; Falcão, I.d.A.; Souza, J.D.S.; Rocha, T.; de Sousa, I.; Cavalcante, A.; de Oliveira, A.; de Sousa, M.; dos Santos, J. Designing of nanomaterials-based enzymatic biosensors: Synthesis, properties, and applications. Electrochem 2021, 2, 149-184. [CrossRef]

216. Aldhahri, M.M.; Almulaiky, Y.Q.; El-Shishtawy, R.M.; Al-Shawafi, W.; Alngadh, A.; Maghrabi, R. Facile immobilization of enzyme via co-electrospinning: A simple method for enhancing enzyme reusability and monitoring an activity-based organic semiconductor. ACS Omega 2018, 3, 6346-6350. [CrossRef]

217. Brites, M.D.M.; Cerón, A.A.; Costa, S.M.; Oliveira, R.C.; Ferraz, H.G.; Catalani, L.H.; Costa, S.A. Bromelain immobilization in cellulose triacetate nanofiber membranes from sugarcane bagasse by electrospinning technique. Enzym. Microb. Technol. 2019, 132, 109384. [CrossRef]

218. Li, D.; Wang, Q.; Huang, F.; Wei, Q. Electrospun nanofibers for enzyme immobilization. In Electrospinning: Nanofabrication and Applications; Elsevier: Amsterdam, The Netherlands, 2018; pp. 765-781, ISBN 9780323512701.

219. Alonso-González, M.; Corral-González, A.; Felix, M.; Romero, A.; Martin-Alfonso, J. Developing active poly(vinyl alcohol)-based membranes with encapsulated antimicrobial enzymes via electrospinning for food packaging. Int. J. Biol. Macromol. 2020, 162, 913-921. [CrossRef] 
220. Zhang, C.; Li, Y.; Wang, P.; Zhang, H. Electrospinning of nanofibers: Potentials and perspectives for active food packaging. Compr. Rev. Food Sci. Food Saf. 2020, 19, 479-502. [CrossRef]

221. Wang, Z.-G.; Wan, L.-S.; Liu, Z.-M.; Huang, X.-J.; Xu, Z.-K. Enzyme immobilization on electrospun polymer nanofibers: An overview. J. Mol. Catal. B Enzym. 2009, 56, 189-195. [CrossRef]

222. Fan, Y.; Tian, X.; Zheng, L.; Jin, X.; Zhang, Q.; Xu, S.; Liu, P.; Yang, N.; Bai, H.; Wang, H. Yeast encapsulation in nanofiber via electrospinning: Shape transformation, cell activity and immobilized efficiency. Mater. Sci. Eng. C 2020, 120, 111747. [CrossRef]

223. El-Shishtawy, R.M.; Aldhahri, M.; Almulaiky, Y.Q. Dual immobilization of $\alpha$-amylase and horseradish peroxidase via electrospinning: A proof of concept study. Int. J. Biol. Macromol. 2020, 163, 1353-1360. [CrossRef]

224. Jun, S.-H.; Yang, J.; Jeon, H.; Kim, H.S.; Pack, S.P.; Jin, E.; Kim, J. Stabilized and immobilized carbonic anhydrase on electrospun nanofibers for enzymatic CO2 conversion and utilization in expedited microalgal growth. Environ. Sci. Technol. 2020, 54, 1223-1231. [CrossRef]

225. Kamaci, U.D.; Peksel, A. enhanced catalytic activity of immobilized phytase into polyvinyl alcohol-sodium alginate based electrospun nanofibers. Catal. Lett. 2020, 151, 821-831. [CrossRef]

226. Chen, H.; Cheng, K.; Hsu, R.; Hsieh, C.; Wang, H.; Ting, Y. Enzymatic degradation of ginkgolic acid by laccase immobilized on novel electrospun nanofiber mat. J. Sci. Food Agric. 2020, 100, 2705-2712. [CrossRef]

227. Jhuang, J.-R.; Lin, S.-B.; Chen, L.-C.; Lou, S.-N.; Chen, S.-H.; Chen, H.-H. Development of immobilized laccase-based time temperature indicator by electrospinning zein fiber. Food Packag. Shelf Life 2019, 23, 100436. [CrossRef]

228. Syukri, M.S.M.; Rahman, R.A.; Mohamad, Z.; Illias, R.M.; Mahmood, N.A.N.; Jaafar, N.R. Optimization strategy for laccase immobilization on polyethylene terephthalate grafted with maleic anhydride electrospun nanofiber mat. Int. J. Biol. Macromol. 2020, 166, 876-883. [CrossRef] [PubMed]

229. Zdarta, J.; Staszak, M.; Jankowska, K.; Kaźmierczak, K.; Degórska, O.; Nguyen, L.N.; Kijeńska-Gawrońska, E.; Pinelo, M.; Jesionowski, T. The response surface methodology for optimization of tyrosinase immobilization onto electrospun polycaprolactonechitosan fibers for use in bisphenol A removal. Int. J. Biol. Macromol. 2020, 165, 2049-2059. [CrossRef]

230. Alvarado-Ramírez, L.; Rostro-Alanis, M.; Rodríguez-Rodríguez, J.; Castillo-Zacarías, C.; Sosa-Hernández, J.E.; Barceló, D.; Iqbal, H.M.; Parra-Saldívar, R. Exploring current tendencies in techniques and materials for immobilization of laccases-A review. Int. J. Biol. Macromol. 2021, 181, 683-696. [CrossRef] [PubMed]

231. Kuang, L.; Zhang, Q.; Li, J.; Tian, H. Preparation of lipase-electrospun SiO2 nanofiber membrane bioreactors and their targeted catalytic ability at the macroscopic oil-water interface. J. Agric. Food Chem. 2020, 68, 8362-8369. [CrossRef]

232. Işik, C.; Arabaci, G.; Doğaç, Y.I.; Deveci, I.; Teke, M. Synthesis and characterization of electrospun PVA/Zn2+ metal composite nanofibers for lipase immobilization with effective thermal, pH stabilities and reusability. Mater. Sci. Eng. C 2019, 99, 1226-1235. [CrossRef] [PubMed]

233. Anandharamakrishnan, C.; Parthasarathi, S. (Eds.) Food Nanotechnology; CRC Press: Boca Raton, FL, USA, 2019; ISBN 9781315153872.

234. Coelho, S.C.; Estevinho, B.N.; Rocha, F. Encapsulation in food industry with emerging electrohydrodynamic techniques: Electrospinning and electrospraying-A review. Food Chem. 2020, 339, 127850. [CrossRef] [PubMed]

235. Morato, N.M.; Holden, D.T.; Cooks, R.G. High-throughput label-free enzymatic assays using desorption electrospray-ionization mass spectrometry. Angew. Chem. Int. Ed. 2020, 59, 20459-20464. [CrossRef] [PubMed]

236. Soares, R.M.; Siqueira, N.; Prabhakaram, M.P.; Ramakrishna, S. Electrospinning and electrospray of bio-based and natural polymers for biomaterials development. Mater. Sci. Eng. C 2018, 92, 969-982. [CrossRef]

237. Bhushani, J.A.; Anandharamakrishnan, C. Electrospinning and electrospraying techniques: Potential food based applications. Trends Food Sci. Technol. 2014, 38, 21-33. [CrossRef]

238. Chen, H.-Y.; Ting, Y.; Kuo, H.-C.; Hsieh, C.-W.; Hsu, H.-Y.; Wu, C.-N.; Cheng, K.-C. Enzymatic degradation of ginkgolic acids by laccase immobilized on core/shell $\mathrm{Fe} 3 \mathrm{O} 4$ /nylon composite nanoparticles using novel coaxial electrospraying process. Int. J. Biol. Macromol. 2021, 172, 270-280. [CrossRef] [PubMed]

239. Che, S.; Wang, J.; Ji, X.; Su, Z.; Wang, S.; Zhang, S. Positional assembly of multi-enzyme cascade reaction in polyelectrolyte doped microcapsule through electrospray and layer-by-layer assembly. Synth. Syst. Biotechnol. 2020, 5, 206-213. [CrossRef]

240. Rentería-Ortega, M.; Salgado-Cruz, M.D.L.P.; Morales-Sánchez, E.; Alamilla-Beltrán, L.; Valdespino-León, M.; CalderónDomínguez, G. Glucose oxidase release of stressed chia mucilage-sodium alginate capsules prepared by electrospraying. J. Food Process. Preserv. 2021, 45, e15484. [CrossRef]

241. Ibili, H.; Dasdemir, M.; Çankaya, T.; Orhan, M.; Güneşoğlu, C.; Anul, S.A. Investigation of poly(lactic acid) nanocapsules containing the plant extract via coaxial electrospraying method for functional nonwoven applications. J. Ind. Text. 2021. [CrossRef]

242. Xing, X.; Han, Y.; Jiang, Q.; Sun, Y.; Wang, X.; Qu, G.; Sun, G.; Li, Y. Immobilization of laccases onto cellulose nanocrystals derived from waste newspaper: Relationship between immobilized laccase activity and dialdehyde content. Cellulose 2021, 1-13. [CrossRef]

243. Lim, L.-T. Electrospinning and electrospraying technologies for food and packaging applications. In Electrospun Polymers and Composites; Woodhead Publishing: Cambridge, UK, 2020; pp. 217-259. [CrossRef]

244. Liu, N.; Li, D.; Wang, W.; Hollmann, F.; Xu, L.; Ma, Y.; Yang, B.; Bai, W.; Sun, X.; Wang, Y. Production and immobilization of lipase PCL and its application in synthesis of $\alpha$-linolenic acid-rich diacylglycerol. J. Food Biochem. 2018, 42, e12574. [CrossRef] 
245. Rostamabadi, H.; Falsafi, S.R.; Rostamabadi, M.M.; Assadpour, E.; Jafari, S.M. Electrospraying as a novel process for the synthesis of particles/nanoparticles loaded with poorly water-soluble bioactive molecules. Adv. Colloid Interface Sci. 2021, $290,102384$. [CrossRef] [PubMed]

246. Li, Y.; Wu, H.; Su, Z. Enzyme-based hybrid nanoflowers with high performances for biocatalytic, biomedical, and environmental applications. Coord. Chem. Rev. 2020, 416, 213342. [CrossRef]

247. Tang, Q.; Zhang, L.; Tan, X.; Jiao, L.; Wei, Q.; Li, H. Bioinspired synthesis of organic-inorganic hybrid nanoflowers for robust enzyme-free electrochemical immunoassay. Biosens. Bioelectron. 2019, 133, 94-99. [CrossRef] [PubMed]

248. Cheon, H.J.; Adhikari, M.D.; Chung, M.; Tran, T.D.; Kim, J.; Kim, M.I. Magnetic nanoparticles-embedded enzyme-inorganic hybrid nanoflowers with enhanced peroxidase-like activity and substrate channeling for glucose biosensing. Adv. Heal. Mater. 2019, 8, e1801507. [CrossRef]

249. Chui, C.-Y.; Ye, H. Fundamental concepts and insights into electrospraying for biomedical applications. In Biomedical Applications of Electrospinning and Electrospraying; Woodhead Publishing: Cambridge, UK, 2021; pp. 185-206. [CrossRef]

250. Li, H.; Hou, J.; Duan, L.; Ji, C.; Zhang, Y.; Chen, V. Graphene oxide-enzyme hybrid nanoflowers for efficient water soluble dye removal. J. Hazard. Mater. 2017, 338, 93-101. [CrossRef]

251. Lee, S.W.; Cheon, S.A.; Kim, M.I.; Park, T.J. Organic-inorganic hybrid nanoflowers: Types, characteristics, and future prospects. J. Nanobiotechnology 2015, 13, 1-10. [CrossRef]

252. An, S.S.; Park, H.G.; Kim, M.I.; Batule, B.; Park, K.S. Ultrafast sonochemical synthesis of protein-inorganic nanoflowers. Int. J. Nanomed. 2015, ume 10, 137-142. [CrossRef]

253. Batule, B.S.; Park, K.S.; Gautam, S.; Cheon, H.J.; Kim, M.I.; Park, H.G. Intrinsic peroxidase-like activity of sonochemically synthesized protein copper nanoflowers and its application for the sensitive detection of glucose. Sens. Actuators B Chem. 2018, 283, 749-754. [CrossRef]

254. Zhang, M.; Zhang, Y.; Yang, C.; Ma, C.; Tang, J. Enzyme-inorganic hybrid nanoflowers: Classification, synthesis, functionalization and potential applications. Chem. Eng. J. 2021, 415, 129075. [CrossRef]

255. Soni, S.; Dwivedee, B.P.; Banerjee, U.C. An ultrafast sonochemical strategy to synthesize lipase-manganese phosphate hybrid nanoflowers with promoted biocatalytic performance in the kinetic resolution of $\beta$-Aryloxyalcohols. Chem. Nano Mat. 2018, 4, 1007-1020. [CrossRef]

256. Chung, M.; Nguyen, T.L.; Tran, T.Q.N.; Yoon, H.H.; Kim, I.T.; Kim, M.I. Ultrarapid sonochemical synthesis of enzyme-incorporated copper nanoflowers and their application to mediatorless glucose biofuel cell. Appl. Surf. Sci. 2018, 429, 203-209. [CrossRef]

257. Park, K.S.; Batule, B.S.; Chung, M.; Kang, K.S.; Park, T.J.; Kim, M.I.; Park, H.G. A simple and eco-friendly one-pot synthesis of nuclease-resistant DNA-inorganic hybrid nanoflowers. J. Mater. Chem. B 2017, 5, 2231-2234. [CrossRef] [PubMed]

258. Liu, X.; Zhao, J.; Zhang, Z.; Jiang, Y.; Bilal, M.; Jiang, Y.; Jia, S.; Cui, J. Self-assembly of activated lipase hybrid nanoflowers with superior activity and enhanced stability. Biochem. Eng. J. 2020, 158, 107582. [CrossRef]

259. Liu, Y.; Shao, X.; Kong, D.; Li, G.; Li, Q. Immobilization of thermophilic lipase in inorganic hybrid nanoflower through biomimetic mineralization. Colloids Surfaces B Biointerfaces 2020, 197, 111450. [CrossRef] [PubMed]

260. Lei, J.; Qi, L.; Luo, Z. Pickering emulsion-based microreactors for size-selective interfacial enzymatic catalysis. Front. Bioeng. Biotechnol. 2020, 8, 950. [CrossRef] [PubMed]

261. Sun, M.; Yin, W.; Chen, J.; Wang, W.; Guo, T.; Meng, T. Hollow colloidosomes with an enzyme confined in a porous shell as Pickering interfacial biocatalysts for efficient bioconversions. Green Chem. 2020, 23, 740-744. [CrossRef]

262. Yang, Y.; Fang, Z.; Chen, X.; Zhang, W.; Xie, Y.; Chen, Y.; Liu, Z.; Yuan, W. An overview of pickering emulsions: Solid-particle materials, classification, morphology, and applications. Front. Pharmacol. 2017, 8, 287. [CrossRef]

263. Jiang, H.; Li, Y.; Hong, L.; Ngai, T. Submicron inverse pickering emulsions for highly efficient and recyclable enzymatic Catalysis. Chem. Asian J. 2018, 13, 3533-3539. [CrossRef]

264. Albert, C.; Beladjine, M.; Tsapis, N.; Fattal, E.; Agnely, F.; Huang, N. Pickering emulsions: Preparation processes, key parameters governing their properties and potential for pharmaceutical applications. J. Control. Release 2019, 309, 302-332. [CrossRef]

265. Dong, Z.; Liu, Z.; Shi, J.; Tang, H.; Xiang, X.; Huang, F.; Zheng, M.-M. Carbon nanoparticle-stabilized pickering emulsion as a sustainable and high-performance interfacial catalysis platform for enzymatic esterification/transesterification. ACS Sustain. Chem. Eng. 2019, 7, 7619-7629. [CrossRef]

266. Sun, T.; Dong, Z.; Wang, J.; Huang, F.-H.; Zheng, M.-M. Ultrasound-assisted interfacial immobilization of lipase on hollow mesoporous silica spheres in a pickering emulsion system: A hyperactive and sustainable biocatalyst. ACS Sustain. Chem. Eng. 2020, 8, 17280-17290. [CrossRef]

267. Wang, J.; Huang, R.; Qi, W.; Su, R.; He, Z. Oriented enzyme immobilization at the oil/water interface enhances catalytic activity and recyclability in a pickering emulsion. Langmuir 2017, 33, 12317-12325. [CrossRef] [PubMed]

268. Wei, L.; Zhang, M.; Zhang, X.; Xin, H.; Yang, H. Pickering emulsion as an efficient platform for enzymatic reactions without stirring. ACS Sustain. Chem. Eng. 2016, 4, 6838-6843. [CrossRef]

269. Lou, W.-Y.; Fernández-Lucas, J.; Ge, J.; Wu, C. Editorial: Enzyme or whole cell immobilization for efficient biocatalysis: Focusing on novel supporting platforms and immobilization techniques. Front. Bioeng. Biotechnol. 2021, 9. [CrossRef]

270. Sarkar, A.; Zhang, S.; Holmes, M.; Ettelaie, R. Colloidal aspects of digestion of Pickering emulsions: Experiments and theoretical models of lipid digestion kinetics. Adv. Colloid Interface Sci. 2018, 263, 195-211. [CrossRef] [PubMed] 
271. Guan, T.; Liu, B.; Wang, R.; Huang, Y.; Luo, J.; Li, Y. The enhanced fatty acids flavor release for low-fat cheeses by carrier immobilized lipases on O/W Pickering emulsions. Food Hydrocoll. 2021, 116, 106651. [CrossRef]

272. Wang, T.; Chen, K.; Li, Z.; Jiang, L.; Yu, D.; Cheng, J.; Wang, L. Construction of an enzyme-Pickering emulsion catalytic system and its application in the interfacial catalytic reaction of rice bran oil deacidification. LWT 2021, 150, 111921. [CrossRef]

273. Yuan, S.; Liu, Q.; Zhu, L.; Ning, J.; Yang, H.; Ning, K.; He, Y. Emulsion hydrogel microbeads encapsulating extractants prepared by $\mathrm{O} / \mathrm{W} / \mathrm{O}$ double pickering emulsions for the recovery of $\mathrm{Cu}(\mathrm{II})$ from water. Colloids Surfaces A Physicochem. Eng. Asp. 2021, 625, 126932. [CrossRef]

274. Zhang, T.; Xu, J.; Chen, J.; Wang, Z.; Wang, X.; Zhong, J. Protein nanoparticles for Pickering emulsions: A comprehensive review on their shapes, preparation methods, and modification methods. Trends Food Sci. Technol. 2021, 113, 26-41. [CrossRef]

275. Jiang, H.; Liu, L.; Li, Y.; Yin, S.-W.; Ngai, T. Inverse pickering emulsion stabilized by binary particles with contrasting characteristics and functionality for interfacial biocatalysis. ACS Appl. Mater. Interfaces 2020, 12, 4989-4997. [CrossRef]

276. Dong, H.; Zhang, W.; Zhou, S.; Huang, J.; Wang, P. Engineering bioscaffolds for enzyme assembly. Biotechnol. Adv. 2021, 107721. [CrossRef]

277. Zhang, Q.; Bolisetty, S.; Cao, Y.; Handschin, S.; Adamcik, J.; Peng, Q.; Mezzenga, R. Selective and efficient removal of fluoride from water: In situ engineered amyloid fibril/ZrO 2 hybrid membranes. Angew. Chem. Int. Ed. 2019, 58, 6012-6016. [CrossRef]

278. Torres, M.; Sothiselvam, S.; Lu, T.K.; de la Fuente-Nunez, C. Peptide design principles for antimicrobial applications. J. Mol. Biol. 2019, 431, 3547-3567. [CrossRef] [PubMed]

279. Hu, B.; Zhu, M. Reconstitution of cellulosome: Research progress and its application in biorefinery. Biotechnol. Appl. Biochem. 2019, 66, 720-730. [CrossRef]

280. Smith, S.P.; A Bayer, E. Insights into cellulosome assembly and dynamics: From dissection to reconstruction of the supramolecular enzyme complex. Curr. Opin. Struct. Biol. 2013, 23, 686-694. [CrossRef]

281. Kumada, Y.; Kuroki, D.; Yasui, H.; Ohse, T.; Kishimoto, M. Characterization of polystyrene-binding peptides (PS-tags) for site-specific immobilization of proteins. J. Biosci. Bioeng. 2010, 109, 583-587. [CrossRef] [PubMed]

282. Dong, H.; Zhang, W.; Wang, Y.; Liu, D.; Wang, P. Biofilm polysaccharide display platform: A natural, renewable, and biocompatible material for improved lipase performance. J. Agric. Food Chem. 2020, 68, 1373-1381. [CrossRef] [PubMed]

283. Dong, H.; Zhang, W.; Xuan, Q.; Zhou, Y.; Zhou, S.; Huang, J.; Wang, P. Binding peptide-guided immobilization of lipases with significantly improved catalytic performance using escherichia coli BL21(DE3) biofilms as a platform. ACS Appl. Mater. Interfaces 2021, 13, 6168-6179. [CrossRef]

284. Mulinari, J.; Oliveira, J.V.; Hotza, D. Lipase immobilization on ceramic supports: An overview on techniques and materials. Biotechnol. Adv. 2020, 42, 107581. [CrossRef]

285. Zdarta, J.; Meyer, A.S.; Jesionowski, T.; Pinelo, M. Developments in support materials for immobilization of oxidoreductases: A comprehensive review. Adv. Colloid Interface Sci. 2018, 258, 1-20. [CrossRef]

286. Adeel, M.; Bilal, M.; Rasheed, T.; Sharma, A.; Iqbal, H.M. Graphene and graphene oxide: Functionalization and nano-bio-catalytic system for enzyme immobilization and biotechnological perspective. Int. J. Biol. Macromol. 2018, 120, 1430-1440. [CrossRef] [PubMed]

287. Kashefi, S.; Borghei, S.M.; Mahmoodi, N.M. Covalently immobilized laccase onto graphene oxide nanosheets: Preparation, characterization, and biodegradation of azo dyes in colored wastewater. J. Mol. Liq. 2018, 276, 153-162. [CrossRef]

288. Ying, W.; Shi, Z.; Yang, H.; Xu, G.; Zheng, Z.; Yang, J. Effect of alkaline lignin modification on cellulase-lignin interactions and enzymatic saccharification yield. Biotechnol. Biofuels 2018, 11, 1-13. [CrossRef] [PubMed]

289. Pandey, D.; Daverey, A.; Arunachalam, K. Biochar: Production, properties and emerging role as a support for enzyme immobilization. J. Clean. Prod. 2020, 255, 120267. [CrossRef]

290. Mokhtar, N.F.; Rahman, R.N.Z.R.A.; Noor, N.D.M.; Shariff, F.M.; Ali, M.S.M. The immobilization of lipases on porous support by adsorption and hydrophobic interaction method. Catalysts 2020, 10, 744. [CrossRef]

291. Cui, J.D.; Ren, S.; Sun, B.; Jia, S. Optimization protocols and improved strategies for metal-organic frameworks for immobilizing enzymes: Current development and future challenges. Coord. Chem. Rev. 2018, 370, 22-41. [CrossRef]

292. Fopase, R.; Paramasivam, S.; Kale, P.; Paramasivan, B. Strategies, challenges and opportunities of enzyme immobilization on porous silicon for biosensing applications. J. Environ. Chem. Eng. 2020, 8, 104266. [CrossRef]

293. Alnoch, R.C.; Dos Santos, L.A.; De Almeida, J.M.; Krieger, N.; Mateo, C. Recent trends in biomaterials for immobilization of lipases for application in non-conventional media. Catalysts 2020, 10, 697. [CrossRef]

294. Liu, J.; Ma, R.-T.; Shi, Y.-P. “Recent advances on support materials for lipase immobilization and applicability as biocatalysts in inhibitors screening methods"-A review. Anal. Chim. Acta 2019, 1101, 9-22. [CrossRef]

295. Bilal, M.; Fernandes, C.D.; Mehmood, T.; Nadeem, F.; Tabassam, Q.; Ferreira, L.F.R. Immobilized lipases-based nano-biocatalytic systems-A versatile platform with incredible biotechnological potential. Int. J. Biol. Macromol. 2021, 175, 108-122. [CrossRef] [PubMed]

296. Jiang, Y.; Liu, X.; Wang, L.; Zhou, L.; Huang, Z.; Ma, L.; He, Y.; Shi, L.; Gao, J. Virus-like organosilica nanoparticles for lipase immobilization: Characterization and biocatalytic applications. Biochem. Eng. J. 2019, 144, 125-134. [CrossRef]

297. Tacias-Pascacio, V.G.; Virgen-Ortíz, J.J.; Jiménez-Pérez, M.; Yates, M.; Torrestiana-Sanchez, B.; Rosales-Quintero, A.; FernandezLafuente, R. Evaluation of different lipase biocatalysts in the production of biodiesel from used cooking oil: Critical role of the immobilization support. Fuel 2017, 200, 1-10. [CrossRef] 
298. Zare, A.; Bordbar, A.-K.; Jafarian, F.; Tangestaninejad, S. Candida rugosa lipase immobilization on various chemically modified Chromium terephthalate MIL-101. J. Mol. Liq. 2018, 254, 137-144. [CrossRef]

299. Xiang, X.; Suo, H.; Xu, C.; Hu, Y. Covalent immobilization of lipase onto chitosan-mesoporous silica hybrid nanomaterials by carboxyl functionalized ionic liquids as the coupling agent. Colloids Surfaces B Biointerfaces 2018, 165, 262-269. [CrossRef]

300. Asmat, S.; Anwer, A.H.; Husain, Q. Immobilization of lipase onto novel constructed polydopamine grafted multiwalled carbon nanotube impregnated with magnetic cobalt and its application in synthesis of fruit flavours. Int. J. Biol. Macromol. 2019, 140, 484-495. [CrossRef]

301. Wan, D.; Tian, L.; Li, X.; Li, B.; Zhang, Q. A versatile strategy for enzyme immobilization: Fabricating lipase/inorganic hybrid nanostructures on macroporous resins with enhanced catalytic properties. Biochem. Eng. J. 2018, 139, 101-108. [CrossRef]

302. Asmat, S.; Husain, Q. Exquisite stability and catalytic performance of immobilized lipase on novel fabricated nanocellulose fused polypyrrole/graphene oxide nanocomposite: Characterization and application. Int. J. Biol. Macromol. 2018, 117, 331-341. [CrossRef] [PubMed]

303. Zhang, L.; Sun, Y. Poly(carboxybetaine methacrylate)-grafted silica nanoparticle: A novel carrier for enzyme immobilization. Biochem. Eng. J. 2018, 132, 122-129. [CrossRef]

304. Cai, Q.; Hu, C.; Yang, N.; Wang, Q.; Wang, J.; Pan, H.; Hu, Y.; Ruan, C. Enhanced activity and stability of industrial lipases immobilized onto spherelike bacterial cellulose. Int. J. Biol. Macromol. 2017, 109, 1174-1181. [CrossRef]

305. Liu, X.; Fang, Y.; Yang, X.; Li, Y.; Wang, C. Electrospun nanofibrous membranes containing epoxy groups and hydrophilic polyethylene oxide chain for highly active and stable covalent immobilization of lipase. Chem. Eng. J. 2018, 336, 456-464. [CrossRef]

306. Gricajeva, A.; Kazlauskas, S.; Kaledienè, L.; Bendikienè, V. Analysis of Aspergillus sp. lipase immobilization for the application in organic synthesis. Int. J. Biol. Macromol. 2018, 108, 1165-1175. [CrossRef]

307. Orrego, A.H.; Ghobadi, R.; Moreno-Perez, S.; Mendoza, A.J.; Fernández-Lorente, G.; Guisan, J.M.; Rocha-Martin, J. Stabilization of immobilized lipases by intense intramolecular cross-linking of their surfaces by using aldehyde-dextran polymers. Int. J. Mol. Sci. 2018, 19, 553. [CrossRef]

308. Sipponen, M.H.; Farooq, M.; Koivisto, J.; Pellis, A.; Seitsonen, J.; Österberg, M. Spatially confined lignin nanospheres for biocatalytic ester synthesis in aqueous media. Nat. Commun. 2018, 9, 1-7. [CrossRef]

309. Elias, N.; Chandren, S.; Razak, F.I.A.; Jamalis, J.; Widodo, N.; Wahab, R.A. Characterization, optimization and stability studies on Candida rugosa lipase supported on nanocellulose reinforced chitosan prepared from oil palm biomass. Int. J. Biol. Macromol. 2018, 114, 306-316. [CrossRef]

310. Otari, S.; Patel, S.K.; Kalia, V.C.; Lee, J.-K. One-step hydrothermal synthesis of magnetic rice straw for effective lipase immobilization and its application in esterification reaction. Bioresour. Technol. 2020, 302, 122887. [CrossRef] [PubMed]

311. Zhang, H.; Liu, T.; Zhu, Y.; Hong, L.; Li, T.; Wang, X.; Fu, Y. Lipases immobilized on the modified polyporous magnetic cellulose support as an efficient and recyclable catalyst for biodiesel production from Yellow horn seed oil. Renew. Energy 2019, 145, 1246-1254. [CrossRef]

312. Manan, F.M.A.; Attan, N.; Widodo, N.; Aboul-Enein, H.Y.; Wahab, R.A. Rhizomucor miehei lipase immobilized on reinforced chitosan-chitin nanowhiskers support for synthesis of eugenyl benzoate. Prep. Biochem. Biotechnol. 2018, 48, 92-102. [CrossRef] [PubMed]

313. Fernando, I.S.; Kim, D.; Nah, J.-W.; Jeon, Y.-J. Advances in functionalizing fucoidans and alginates (bio)polymers by structural modifications: A review. Chem. Eng. J. 2018, 355, 33-48. [CrossRef]

314. Jamróz, E.; Kulawik, P.; Kopel, P. The Effect of Nanofillers on the Functional Properties of Biopolymer-Based Films: A Review. Polymers 2019, 11, 675. [CrossRef]

315. Khademian, E.; Salehi, E.; Sanaeepur, H.; Galiano, F.; Figoli, A. A systematic review on carbohydrate biopolymers for adsorptive remediation of copper ions from aqueous environments-part A: Classification and modification strategies. Sci. Total. Environ. 2020, 738, 139829. [CrossRef] [PubMed]

316. Klein, M.; Poverenov, E. Natural biopolymer-based hydrogels for use in food and agriculture. J. Sci. Food Agric. 2020, 100, 2337-2347. [CrossRef]

317. Qi, H.; Du, Y.; Hu, G.; Zhang, L. Poly(carboxybetaine methacrylate)-functionalized magnetic composite particles: A biofriendly support for lipase immobilization. Int. J. Biol. Macromol. 2017, 107, 2660-2666. [CrossRef]

318. Khan, N.; Maseet, M.; Basir, S.F. Synthesis and characterization of biodiesel from waste cooking oil by lipase immobilized on genipin cross-linked chitosan beads: A green approach. Int. J. Green Energy 2019, 17, 84-93. [CrossRef]

319. Motaung, T.E.; Linganiso, L.Z. Critical review on agrowaste cellulose applications for biopolymers. Int. J. Plast. Technol. 2018, 22, 185-216. [CrossRef]

320. Elias, N.; Chandren, S.; Attan, N.; Mahat, N.A.; Razak, F.I.A.; Jamalis, J.; Wahab, R.A. Structure and properties of oil palm-based nanocellulose reinforced chitosan nanocomposite for efficient synthesis of butyl butyrate. Carbohydr. Polym. 2017, 176, 281-292. [CrossRef] [PubMed]

321. Weng, Z.; Wang, J.; Senthil, T.; Wu, L. Mechanical and thermal properties of ABS/montmorillonite nanocomposites for fused deposition modeling 3D printing. Mater. Des. 2016, 102, 276-283. [CrossRef] 